mgr inż. Jakub Kajurek ${ }^{1 *}$, dr hab. inż. Artur Rusowicz, prof. PW ${ }^{1}$

${ }^{1}$ Politechnika Warszawska

Wydział Mechaniczny Energetyki i Lotnictwa

Instytut Techniki Cieplnej

ul. Nowowiejska 21/25, 00-665 Warszawa

*Autor korespondencyjny - e-mail: jakub.kajurek@itc.pw.edu.pl

\title{
KIERUNKI ROZWOJU I BADAŃ TERMOAKUSTYCZNYCH URZĄDZEŃ CHLODNICZYCH Z FALĄ STOJĄCĄ
}

\section{Streszczenie}

Chłodzenie termoakustyczne to perspektywiczna technologia, która wykorzystuje energię fali akustycznej do transportu ciepła z ośrodka o niskiej do ośrodka o wysokiej temperaturze. Do głównych zalet tej technologii zalicza się dużą niezawodność, prostą konstrukcję urządzeń, a przede wszystkim brak szkodliwych dla środowiska czynników chłodniczych. Z drugiej strony wadą tej technologii jest relatywnie niska sprawność w porównaniu do współczesnych rozwiązań konwencjonalnych. Głównie z tej przyczyny urządzenia termoakustyczne wciąż pozostają $\mathrm{W}$ fazie szerokich badań mających na celu poprawę ich wydajności. $\mathrm{W}$ artykule tym przedstawiono kierunki obecnie prowadzanych prac. Uwagę zwrócono zwłaszcza na badania eksperymentalne $\mathrm{z}$ zakresu wyboru optymalnych parametrów konstrukcyjnych i eksploatacyjnych termoakustycznych urządzeń chłodniczych $\mathrm{z}$ falą stojącą. Omówiono również budowę oraz podstawową zasadę działania takich urządzeń.

Słowa kluczowe: perspektywiczna technologia chłodnicza, termoakustyka, chłodzenie termoakustyczne, termoakustyczne urządzenie chłodnicze.

\section{THE DIRECTIONS OF DEVELOPMENT AND RESEARCH ON THE THERMOACOUSTIC REFRIGERATORS WITH THE STANDING WAVE}

\begin{abstract}
Thermoacoustic refrigeration is a perspective technology capable of transporting heat from a low-temperature source to a high-temperature source by utilizing the acoustic power input. It shows the advantages of high reliability, simple construction and operating without hazardous refrigerants. On the other hand, this technology has disadvantage of relative low efficiency in comparison to conventional solutions. Thus, many efforts have been taken in order to improve the performance of the thermoacoustic coolers. The article presents the review of current research. The main attention is focused on the experimental investigations of the optimal selection of the design and the operational parameters of the thermoacoustic refrigerators with the standing wave. The construction and principles of operations of such devices are also described in this paper.

Keywords: perspective cooling technology, thermoacoustics, thermoacoustic refrigeration, thermoacoustic refrigerator
\end{abstract}




\section{Wprowadzenie}

Regulacje prawne dotyczące wycofywania z użycia szkodliwych dla atmosfery czynników chłodniczych oraz powszechny wzrost świadomości ekologicznej zapoczątkowały wiele badań nad przyjaznymi dla środowiska substancjami roboczymi czy alternatywnymi technologiami chłodniczymi. Jedną $\mathrm{z}$ opcji należącą do drugiej grupy rozwiązań jest chłodzenie termoakustyczne, które nie wymaga stosowania czynników chłodniczych [1]. Technologia ta jest nadal w fazie rozwoju, gdyż większość urządzeń wciąż powstaje głównie w ośrodkach naukowych, jednak ze względu na szereg ciekawych właściwości staje się coraz bardziej rozpowszechniana. Poza neutralnymi dla środowiska substancjami roboczymi chłodziarki termoakustyczne charakteryzują się długą żywotnością i dużą niezawodnością. Urządzenia te nie posiadają bowiem elementów ruchomych. Obieg termodynamiczny nie jest tu wymuszany przez ruch części mechanicznych, lecz wynika z właściwości fali akustycznej, czyli odpowiedniego przesunięcia między oscylującą prędkością i ciśnieniem.

Pojęcie ,termoakustyka” zostało wprowadzone przez Nikolausa Rott'a w latach 70 ubiegłego wieku, który opracował również liniową teorię tego zjawiska, jako interdyscyplinarna dziedzina zajmująca się procesami konwersji energii fali akustycznej $\mathrm{w}$ ciepło i odwrotnie [2]. Niemniej pierwsze obserwacje tego efektu mogą być już datowane na rok 1777, w którym to Byron Higgins w swym eksperymencie odkrył zależność pomiędzy oscylacjami akustycznymi a położeniem płomienia wewnątrz szklanego przewodu otwartego $\mathrm{z}$ obu stron [3]. W kolejnych latach prace nad zjawiskiem termoakustycznym były prowadzone m.in. przez Sondhaussa [4], Rijkiego [5] czy Lorda Rayleigha, który w roku 1887 jako pierwszy podjął się próby wyjaśnienia tego zjawiska, zgodnie z którym ,jeśli ciepło dostarczone jest do powietrza w momencie jego największego zagęszczenia i jest odebrane $\mathrm{w}$ momencie jego największego rozrzedzenia to gaz zaczyna oscylować pod warunkiem, że znajduje się w kanale, w którym występuje gradient temperatury" [6]. Przełomem we współczesnej termoakustyce stały się badania prowadzone przez Cartera i jego współpracowników, którzy w roku 1962 zmodyfikowali rurę Sondhaussa umieszczając w jej wnętrzu stos zbudowany z równolegle ułożonych do siebie płytek intensyfikujących zjawisko termoakustyczne. Modyfikacja ta doprowadziła do budowy pierwszego silnika termoakustycznego, który produkował $27 \mathrm{~W}$ mocy akustycznej z $600 \mathrm{~W}$ ciepła [7]. Sukces urządzenia zapoczątkował okres intensywnych prac prowadzonych $\mathrm{W}$ dziedzinie termoakustyki, w których prym wiódł zespół z Los Alamos National Laboratory na czele z G. Swiftem i J. Wheatley [8]. Ich rezultatem było zbudowane przez T. Hofler'a, w oparciu o teorię N. Rott'a, pierwsze termoakustyczne urządzenie chłodnicze o mocy chłodniczej $6 \mathrm{~W}$, dla którego źródło dźwięku stanowił odpowiednio zmodyfikowany głośnik komercyjny o mocy $13 \mathrm{~W}$ [9]. Chłodziarka ta wypełniona była helem pod ciśnieniem 10 bar i pracowała przy częstotliwości $500 \mathrm{~Hz}$, która odpowiadała 1/4 długości fali akustycznej generowanej w rezonatorze. Rezonator ten składał się z trzech sekcji: sekcji o dużej średnicy, sekcji o małej średnicy i sekcji objętości buforowej (Rysunek 4.3 c). Na cześć wynalazcy taki kształt rezonatora przyjęło się nazywać rezonatorem Hofler'a.

Współcześnie powstaje coraz więcej podobnych konstrukcji, które mogłyby znaleźć praktycznie zastosowanie, jednak ich stosunkowo niska efektywność zniechęca potencjalnych inwestorów. Z tego głównie względu wciąż podejmowanych jest wiele prac mających na celu optymalizację pracy chłodziarek termoakustycznych. W artykule tym przedstawiono kierunki obecnie prowadzonych działań. Uwagę skupiono głównie na badaniach eksperymentalnych realizowanych w zakresie termoakustycznych urządzeń chłodniczych $\mathrm{z}$ falą stojącą $\mathrm{w}$ ciągu ostatnich 30 lat. 


\section{Zasada dzialania chłodziarki termoakustycznej}

Zaburzeniom gęstości i ciśnienia ośrodka powodującym miejscowe drgania jego cząsteczek towarzyszą zawsze oscylacje temperatury. Najczęściej takie zmiany temperatury są pomijalne. Sytuacja ulega jednak zmianie jeśli zaburzenia te rozchodzą się w ośrodku porowatym. Wówczas oddziaływania termiczne pomiędzy pulsującym płynem a ciałem stałym prowadzą do zjawiska termoakustycznego, czyli wspólnego transportu i konwersji ciepła w energię fali akustycznej i odwrotnie [10]. Efekt ten ze względu na kierunek przepływu energii można podzielić na dwa rodzaje: pierwszy generuje falę akustyczną w wyniku przepływu ciepła w kierunku przeciwnym do gradientu temperatury ciała stałego, drugi absorbuje energię fali akustycznej powodując wzrost gradientu [11]. W taki sam sposób klasyfikuje się urządzenia wykorzystujące zjawisko termoakustyczne na silniki termoakustyczne, czyli urządzenia, które w wyniku przepływu ciepła z ośrodka o wysokiej temperaturze do ośrodka o niskiej temperaturze generują moc akustyczną, oraz chłodziarki termoakustyczne, które absorbują moc akustyczną w celu transportu ciepła z ośrodka o niskiej temperaturze do ośrodka o wysokiej temperaturze.

Jak napisano wcześniej, obieg termodynamiczny urządzenia termoakustycznego determinuje przesunięcie fazowe pomiędzy ciśnieniem a prędkością akustyczną. Według tego kryterium wyróżnia się urządzenia $\mathrm{z}$ falą stojącą, $\mathrm{W}$ których oscylacja ciśnienia jest przesunięta względem oscylacji prędkości o $\pi / 2$, oraz urządzenia $\mathrm{z}$ falą biegnącą, gdzie oscylacja ciśnienia pozostaje $\mathrm{w}$ fazie $\mathrm{z}$ oscylacją prędkości [7]. Obieg termodynamiczny urządzenia termoakustycznego $\mathrm{z}$ falą stojącą można wytłumaczyć rozważając cienką płytkę umieszczoną $\mathrm{w}$ kierunku stojącej fali akustycznej, na którą nałożony jest średni gradient temperatury $\nabla T_{m}$. W wyniki fali akustycznej porcje płynu znajdujące się $\mathrm{w}$ pobliżu płytki doświadczają zmian ciśnienia, prędkości i temperatury. $Z$ jednej strony zmiany temperatury porcji płynu wynikają z jej adiabatycznego sprężania i rozprężania przez falę akustyczną, $\mathrm{z}$ drugiej są rezultatem wymiany ciepła $\mathrm{z}$ płytą. Wymiana ciepła pomiędzy porcją płynu a płytą $\mathrm{w}$ zakresie głębokości penetracji ciepła wprowadza opóźnienie $\mathrm{w}$ czasie między ruchem płynu a oscylacją temperatury. Opóźnienie to jest niezbędne do realizacji obiegu termodynamicznego [10].

W zależności od nałożonego na płytę średniego gradientu temperatury obieg realizowany przez porcję płynu może być obiegiem silnikowym lub obiegiem chłodniczym. Wartością graniczną jest tzw. krytyczny gradient temperatury $\left(\nabla T_{c r i t}\right)$, czyli wartość, dla której zmiany temperatury porcji płynu $\mathrm{w}$ wyniku jej adiabatycznego sprężania i rozprężania przez falę akustyczną są równe zmianom temperatury wynikającym $\mathrm{z}$ ruchu płynu wzdłuż płyty z nałożonym gradientem temperatury. Dla $\nabla T_{m}<\nabla T_{\text {crit }}$ energia akustyczna jest absorbowana i ciepło jest transportowane $\mathrm{z}$ ośrodka o niższej do ośrodka o wyższej temperaturze - obieg chłodniczy. Z kolei dla $\nabla T_{m}>\nabla T_{\text {crit }}$ energia akustyczna jest generowana wskutek przepływu ciepła z ośrodka o temperaturze wyższej do ośrodka o temperaturze niższej - obieg silnikowy [11].

Obieg termodynamiczny termoakustycznego urządzenia chłodniczego $\mathrm{z}$ falą stojąca można w uproszczeniu rozważać jako cztery niezależne przemiany (Rysunek 2.1). W pierwszym etapie porcja płynu sprężana jest adiabatycznie przez falą akustyczną i porusza się w kierunku strzałki ciśnienia czemu towarzyszy także wzrost jej temperatury o wartość $2 T_{1}$. Po przemieszczeniu temperatura porcji płynu jest wyższa od miejscowej temperatury płyty co powoduje izobaryczny przepływ ciepła od płynu do płyty. W trzeciej przemianie porcja płynu wraca do swej początkowej pozycji, ochładza i rozpręża się adiabatycznie. Przy maksymalnym wychyleniu $\mathrm{w}$ przeciwnym kierunku temperatura płynu jest niższa niż temperatura płyty, stąd następuje ponowny przepływ ciepła przy stałym ciśnieniu tym razem od płyty do płynu. Po tym procesie porcja płynu osiąga swoje początkowe parametry [10]. 


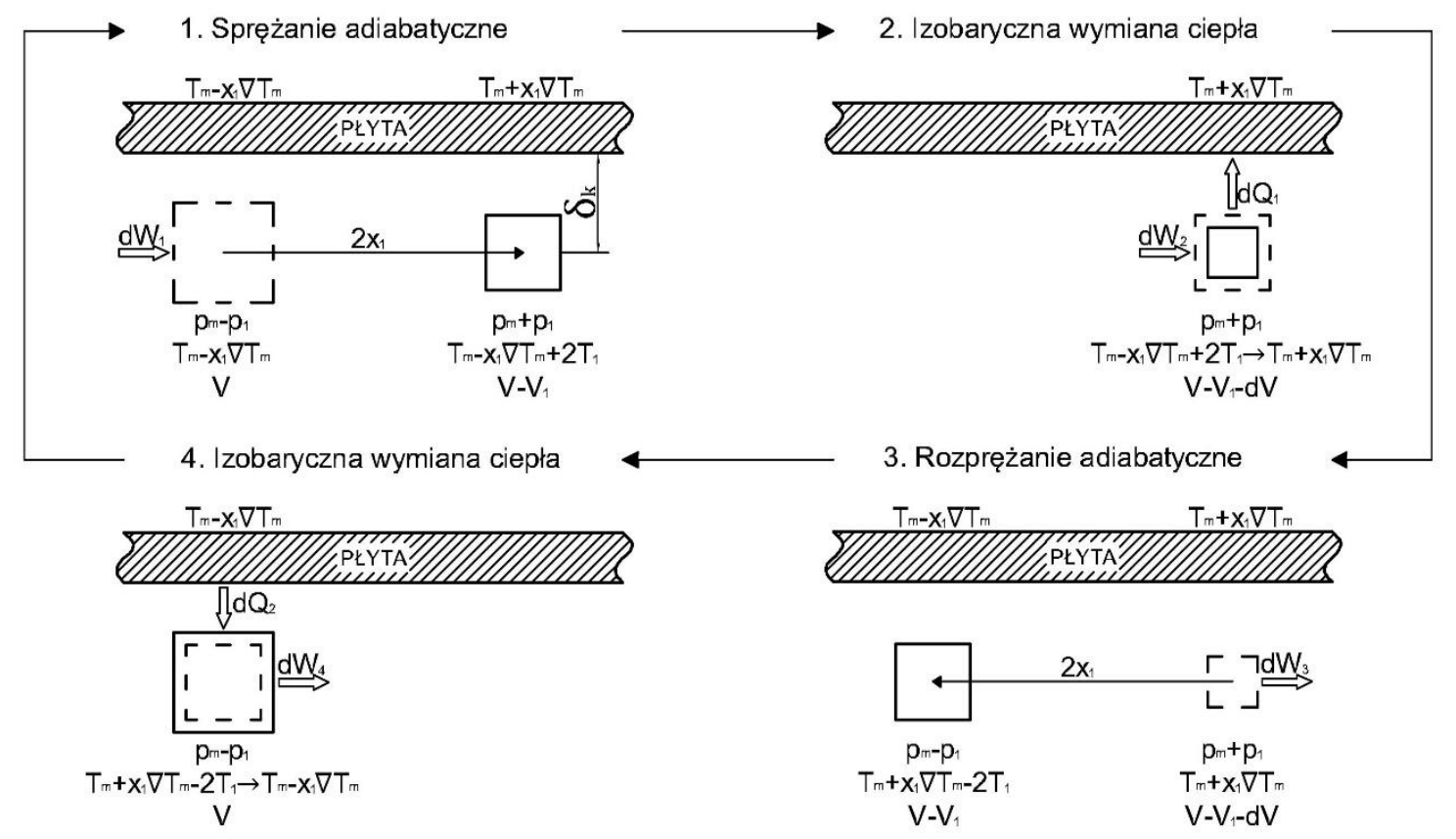

Rysunek 2.1: Obieg termodynamiczny termoakustycznego urządzenia chłodniczego

Najczęściej długość płyty jest większa od przemieszczenia pojedynczej porcji płynu. $\mathrm{Z}$ tego względu do transportu ciepła $\mathrm{z}$ jednego do drugiego krańca płyty wykorzystywanych jest wiele porcji płynu, z których każda realizuje obieg termodynamiczny. W pierwszym półcyklu poszczególne porcje płynu transportują ciepło w ilości $d Q$ na odległość swego maksymalnego przemieszczenia, po czym przekazują je płycie. W drugim półcyklu porcje płynu ponownie wracają do swojego początkowego położenia, w którym pobierają od płyty ciepło pozostawione $\mathrm{w}$ pierwszym półcyklu przez porcje płynu sąsiadujące $\mathrm{z}$ nimi (Rysunek 2.2). Wobec takiego zachowania wzdłuż płyty transportowana jest stała ilość ciepła, zaś płyta stanowi jedynie chwilowy magazyn ciepła [12].

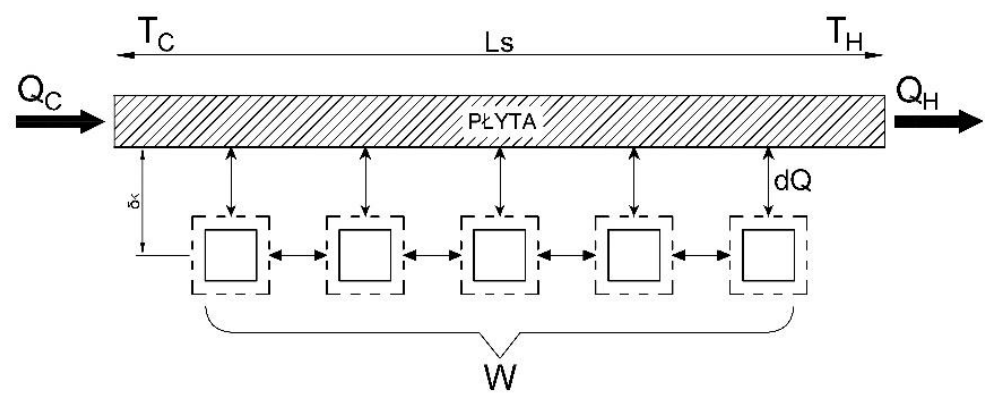

Rysunek 2.2: Transport ciepła wzdłuż płyty.

Ilość ciepła transportowanego wzdłuż jednej płyty w opisany wyżej sposób jest niewielka. W celu intensyfikacji efektu pomnaża się liczbę równolegle ułożonych do siebie płyt, które tworzą wówczas tzw. stos. Stos to inaczej element porowaty, dla którego średnica hydrauliczna poru jest większa od głębokości wnikania ciepła $\left(N_{L}=r_{h} / \delta_{k} \geq 1\right.$, gdzie $N_{L}$ to liczba Lautreca), i który może przybierać różne kształty, np. równolegle ułożonych do siebie płyt czy kształt plastra miodu [13]. W celu wykorzystania zjawiska termoakustycznego do transportu ciepła w urządzeniu chłodniczym (w silniku również) do krańców stosu mocuje się wymienniki ciepła, tzw. zimny wymiennik ciepła, który transportuje ciepło z dolnego źródła 
ciepła do zimnej strony stosu, oraz gorący wymiennik ciepła, który odbiera ciepło od ciepłej strony stosu i przekazuje je do górnego źródła ciepła. Wszystkie te elementy umieszczone są $\mathrm{w}$ rezonatorze wypełnionym czynnikiem roboczym, który izoluje pole akustyczne od otoczenia. Źródłem energii akustycznej zasilającej urządzenie może być silnik termoakustyczny lub przetwornik akustyczny np. głośnik komercyjny. Uproszczona budowa chłodziarki termoakustycznej z falą stojącą przedstawiona jest na Rysunku 2.3.

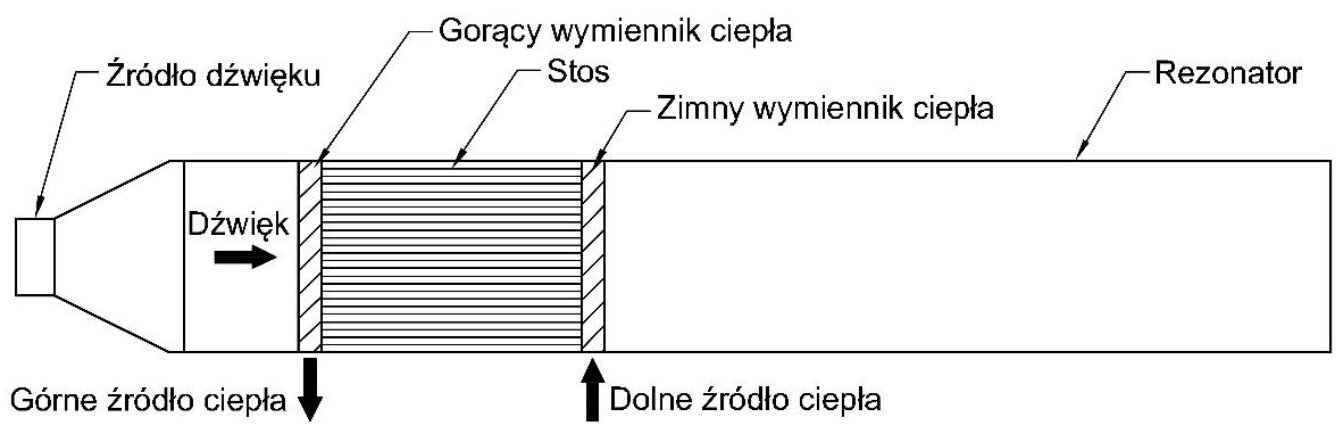

Rysunek 2.3: Budowa termoakustycznego urządzenia chłodniczego z falą stojącą.

\section{Kierunki badań urządzeń termoakustycznych}

Technologia termoakustyczna oferuje wiele możliwości opracowania innowacyjnych rozwiązań w zakresie chłodnictwa. Chłodziarki termoakustyczne pozwalają m.in. na osiąganie niskich temperatur za pomocą jednego urządzenia czy wykorzystanie ciepła odpadowego do produkcji chłodu w przypadku, gdy źródło dźwięku stanowi silnik termoakustyczny. Relatywnie niska wydajność urządzeń w stosunku do systemów komercyjnych sprawia, że wszystkie zalety tej technologii często spychane są na dalszy plan. $\mathrm{Z}$ tej przyczyny badania dotyczące chłodniczych urządzeń termoakustycznych sprowadzają się niejednokrotnie do badania samego zjawiska termoakustycznego i czynników, które na niego wpływają. Badania te odnoszą zarówno do parametrów geometrycznych wpływających na zjawisko termoakustyczne, a przez to i na pracę chłodziarki tj. pozycja i długość stosu, porowatość stosu czy długość rezonatora, jak i parametrów eksploatacyjnych tj. częstotliwość robocza, ciśnienie robocze czy rodzaj czynnika roboczego. Do pozostałych kierunków badań należy zaliczyć [14]:

- badania nad źródłem energii akustycznej - elektromechanicznymi generatorami dźwięku zapewaniającymi odpowiednio dużą amplitudę ciśnienia fali;

- badania nad alternatywnymi materiałami stosu, np. materiałami anizotropowymi;

- badania nad wymiennikami ciepła urządzeń termoakustycznych jako elementami w znacznym stopniu wpływającymi na wydajność urządzenia;

- badania na efektami nieliniowymi występującymi w urządzeniach termoakustycznych

pracujących przy wysokich amplitudach ciśnienia.

Samo zjawisko termoakustyczne i urządzenia analizowane są różnymi metodami: eksperymentalnymi, analitycznymi i numerycznymi. Analizy te sprowadzają się do wyznaczenia różnicy temperatur powstającej wzdłuż stosu [15-17], współczynnika COP/EER urządzenia bądź stosu [18-20], czy wymaganej mocy akustycznej niezbędnej do otrzymania żądanego efektu chłodniczego [12,21,22]. Badania eksperymentalne często służą demonstracji samego zjawiska termoakustycznego i wyznaczeniu podstawowych parametrów pracy skonstruowanego urządzenia, ale także pozwalają na weryfikację przyjętych metod 
optymalizacyjnych, nierzadko dodatkowo sprawdzanych programem numerycznym DELTAEC. Optymalizowane parametry powiązane są z lokalnym maksimum/minimum funkcji celu: COP urządzenia, wydajność chłodnicza, różnica temperatur, które wyznacza się $\mathrm{np}$. za pomocą uproszczonego liniowego modelu termoakustycznego [12,18], algorytmu genetycznego [23], algorytmu optymizacji roju cząstek (PSO) [24] czy algorytmu TLBO [25].

\section{Przegląd badań eksperymentalnych}

Praca termoakustycznego urządzenia chłodniczego $\mathrm{z}$ falą stojącą jest zależna od 18 parametrów. Do najczęściej badanych w czasie eksperymentów zalicza się: geometria stosu, materiał stosu, położenie stosu, długość stosu, długość i kształt rezonatora, rodzaj i właściwości czynnika roboczego, średnie ciśnienie panujące w rezonatorze, amplituda ciśnienia fali akustycznej oraz częstotliwość fali akustycznej [26].

\section{Geometria stosu}

Stos to podstawowy element urządzenia termoakustycznego, w którym transportowane jest ciepło $\mathrm{z}$ jednego do drugiego krańca. Powinien być tak skonstruowany, aby warstwa przyścienna otaczająca materiał, w której występuje zjawisko termoakustyczne była jak największa. Porowatość stosu wpływająca na wielkości warstwy przyściennej jest funkcją głębokości penetracji ciepła i głębokości penetracji lekkości. Każda porcja płynu roboczego znajdująca się poza warstwą oddziaływań ciepła i lepkości nie będzie odczuwała istnienia płyty. Porcje płynu będą wówczas sprężane i rozprężane w sposób niemal adiabatyczny, efekt termoakustyczny będzie znikomy. Z kolei dla porcji płynu znajdujących się bardzo blisko płyty sprężanie i rozprężanie będą prawie izotermiczne, gdyż porcje te przyjmą temperaturę płyty. Z tych względów rozmiar szczelin powinien mieścić się $\mathrm{w}$ zakresie od 2 do 4 głębokości penetracji ciepła [27]. Dla mniejszych rozmiarów porcje płynu znajdujące się pomiędzy szczelinami ze względu na siły lepkościowe nie będą mogły swobodnie oscylować, zaś dla zbyt dużych rozmiarów porcje płynu będą pracowały bezwartościowo, nie biorąc udziału w zjawisku termoakustycznym. Optymalna porowatość stosu często jednak zależy od celu pracy urządzenia. Tijani i in. w swej pracy [27] wykazali, że rozstaw szczelin dla stosu wykonanego z równolegle ułożonych płyt o wartości ok. 3 głębokości penetracji ciepła zapewnia najwyższy współczynnik EER, o wartości ok 2.5 głębokości penetracji ciepła prowadzi do maksymalnej wydajności chłodniczej urządzenia, zaś o wartości ok. 4 głębokości penetracji ciepła gwarantuje największy spadek temperatury wzdłuż stosu [27]. Swe eksperymenty przeprowadzali na urządzeniu wypełnionym helem pod ciśnieniem 10 bar pracującym z częstotliwością $400 \mathrm{~Hz}$. Zbliżone wyniki dla podobnej konstrukcji stosu otrzymał Setiawan I. i in. [28], w których maksymalny spadek temperatury wystąpił również dla rozstawu szczelin odpowiadającemu ok. 4 głębokościom penetracji ciepła. W przypadku tego zespołu doświadczenia były przeprowadzane dla dwóch częstotliwości 107 i $86 \mathrm{~Hz}$ przy długoścach rezonatora wypełnionego powietrzem pod ciśnienim atomsferycznym równych: 800 i $1000 \mathrm{~mm}$.

Same stosy ze względów praktycznych często wykonuje się w kształcie spirali $\mathrm{z}$ odpowiednim odstępem pomiędzy kolejnymi warstwami materiału czy w postaci równolegle ułożonych do siebie warstw materiału [26]. Do innych typów konstrukcji stosu należy również zaliczyć te ze strukturami porów w postaci plastra miodu, okręgów o odpowiednich średnicach lub czworokątów (Rysunek 4.1). W badaniach eksperymentalnych sprawdzane są także różnego rodzaju materiały porowate o nieregularnej budowie takie jak pianki - np. RVC, czy wełny - np. ze stali nierdzewnej (Tabela 1). Yahya S. G. i in. [16] w swych doświadczeniach badali stosy o budowie nieregularnej takie jak: wełna ze stali nierdzewnej, zmywak miedziany i pianka węglowa oraz stosy o budowie regularnej 
stworzone $\mathrm{z}$ równolegle ułożonych płyt wykonanych z Mylaru i stali nierdzewnej. Z pośród stosów o budowie nieregularnej najwyższą różnicę temperatur otrzymali dla wełny ze stali nierdzewnej, jednak i tak była ona znacznie niższa niż ta uzyskana dla stosów o budowie regularnej. Podobne wnioski wyciągnięto z badań przeprowadzanych przez Tasnim S. i jej zespół [15].
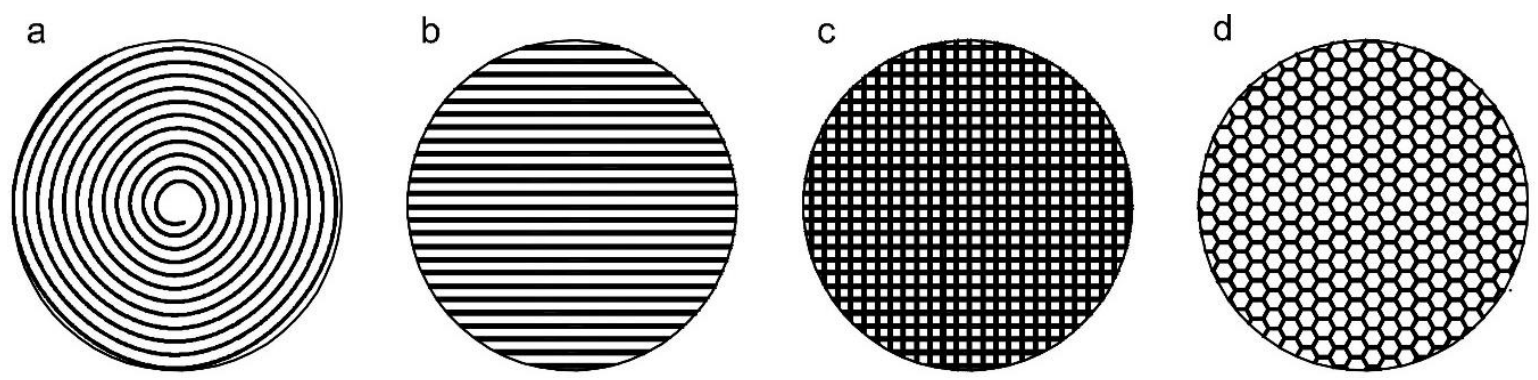

Rysunek 4.1: Geometrie stosów: a) spiralny, b) równolegle ułożone płytki, c) pory kwadratowe, d) plaster miodu.

\section{Material stosu}

Zjawisko termoakustyczne zachodzące w stosie termoakustycznego urządzenia chłodniczego transportuje ciepło $\mathrm{z}$ ośrodka o temperaturze niższej do ośrodka o temperaturze wyższej. Z kolei materiał, z którego wykonany jest stos, kontaktujący się z tymi samymi dwoma ośrodkami transportuje ciepło poprzez przewodzenie w kierunku odwrotnym, tj. $\mathrm{z}$ ośrodka o temperaturze wyższej do ośrodka o temperaturze niższej. W celu minimalizacji ciepła transportowanego przez materiał, które wpływa na zmniejszenie wydajności urządzenia stos powinien być zbudowany z materiału charakteryzującego się niskim współczynnikiem przewodzenia ciepła. $Z$ drugiej strony stos stanowi także chwilowy magazyn ciepła dla porcji płynu dla okresu odpowiadającego oscylacji fali akustycznej. Wysoka wartość współczynnika przewodzenia ciepła w kierunku normalnym do fali akustycznej zwiększy więc ilość ciepła zgromadzonego przez materiał stosu. Wynika więc, że najlepszym rozwiązaniem jest stos wykonany $\mathrm{z}$ materiału anizotropowego o wysokim współczynnik przewodzenia ciepła w kierunku normalnym do fali akustycznej i o niskim współczynniku przewodzenia ciepła w kierunku równoległym. Materiały charakteryzujące się takimi właściwościami, które mogą być wykorzystane $\mathrm{w}$ termoakustyce wciąż pozostają $\mathrm{W}$ fazie rozwoju [29]. W badaniach eksperymentalnych, sprawdzane są natomiast konfiguracje stosów, które wprowadzają anizotropowość przewodzenia ciepła przez stos. Na przykład Bosel J. i in [30] wykazali, że stos zbudowany z segmentów równolegle ułożonych do siebie płytek, z których każdy obrócony jest względem sąsiedniego o $90^{\circ}$ zwiększa COP stosu $\mathrm{w}$ stosunku do stosu bez takich segmentów.

Stos powinien być także odporny na wahania temperatury oscylującego gazu. Z tego względu pojemność cieplna materiału, z którego jest zbudowany powinna być większa od pojemności cieplnej czynnika roboczego [10]. Do najczęściej stosowanych materiałów należy Mylar (Tabela 1). W badaniach eksperymentalnych sprawdzane są także włókno szklane, aluminium, miedź, stal nierdzewna, ceramika, RVC, mika czy klisze fotograficzne. Te ostatnie wykorzystywane są zwłaszcza do budowy stosów spiralnych (Tabela 1). Ich porównanie $\mathrm{w}$ stosunku do stosów wykonanych z Mylaru zostało przeprowadzone przez Hariharan N. i in. [31]. Dla dwóch konstrukcji o odległościach pomiędzy arkuszami 
odpowiednio równymi 0.4 i $0.8 \mathrm{~mm}$ mniejsze różnice temperatur osiągnięto dla stosów zbudowanych z kliszy fotograficznej, stosownie o $1.5 \mathrm{~K}$ dla $0.4 \mathrm{~mm}$ i $3 \mathrm{~K}$ dla $0.8 \mathrm{~mm}$.

\section{Długość i położenie stosu}

Ilość czynnika roboczego biorącego udział w termoakustycznym transporcie ciepła rośnie wraz ze wzrostem długości stosu - rośnie liczba porcji płynu realizujących obiegi termoakustyczne (podpunkt 2.). Dla każdego urządzenia występuje jednak optymalna długość stosu, która gwarantuje maksymalną wydajność, a po przekroczeniu której wydajność zaczyna maleć. Stos staje się wówczas za długi w stosunku do fali akustycznej, gdyż jeden jego kraniec jest zbyt blisko strzałki prędkości, gdzie zachodzą wysokie straty lepkościowe, zaś drugi kraniec jest zbyt blisko strzałki ciśnienia, gdzie występuje niska moc akustyczna. Zależności te zostały potwierdzone między innymi $\mathrm{w}$ badaniach prowadzonych przez Setiawan I. z zespołem [32] i Tasnim S. z zespołem [15].

Długość stosu jest zawsze powiązana z jego położeniem - dla stosów długich optimum ich pracy przesuwa się w kierunków położenia dalszego od źródła dźwięku (Rysunek 4.2). Wybór odpowiedniej lokalizacji elementu wynika z dwóch czynników: mocy akustycznej i dyssypacji energii. Moc akustyczna jest iloczynem ciśnienia i prędkości akustycznej. Przyjmuje wartość zero dla węzłów ciśnienia i prędkości. Dla położenia środka stosu w tych punktach transport ciepła nie będzie możliwy. Umieszczenie stosu bliżej strzałki prędkości niż strzałki ciśnienia ze względu na dużą prędkość akustyczną będzie z kolei powodowało straty wynikające $\mathrm{z}$ lepkości. $Z$ tego powodu stos znajduje się najczęściej bliżej strzałki ciśnienia. Swift w swych pracach zaleca lokalizację odpowiadającą ok. 1/20 długości fali akustycznej od źródła dźwięku, co w wielu przypadkach narzuca konieczność konstrukcji krótkiego stosu [33]. Tijani w swojej pracy określa z kolei lokalizację odpowiadającą 1/8 długości fali akustycznej [34]. W pozostałych pracach optimum znajduje się gdzieś pomiędzy tymi wartościami. Na przykład w pracy [35] optymalne położenie stosu $\mathrm{w}$ rezonatorze wypełnionym powietrzem pod ciśnieniem atmosferycznym dla wszystkich czterech badanych częstotliwości odpowiadało 1/16 długości fali akustycznej. Zbliżoną wartość równą 1/15 długości fali akustycznej uzyskano w [36], gdzie czynnikiem roboczym również było powietrze pod ciśnieniem atmosferycznym, zaś w [37] maksymalne różnice temperatur dla częstotliwości od 150 do $300 \mathrm{~Hz}$ wystąpiły dla położenia środka stosu odpowiadającego od 1/10 do 3/10 długości fali akustycznej.

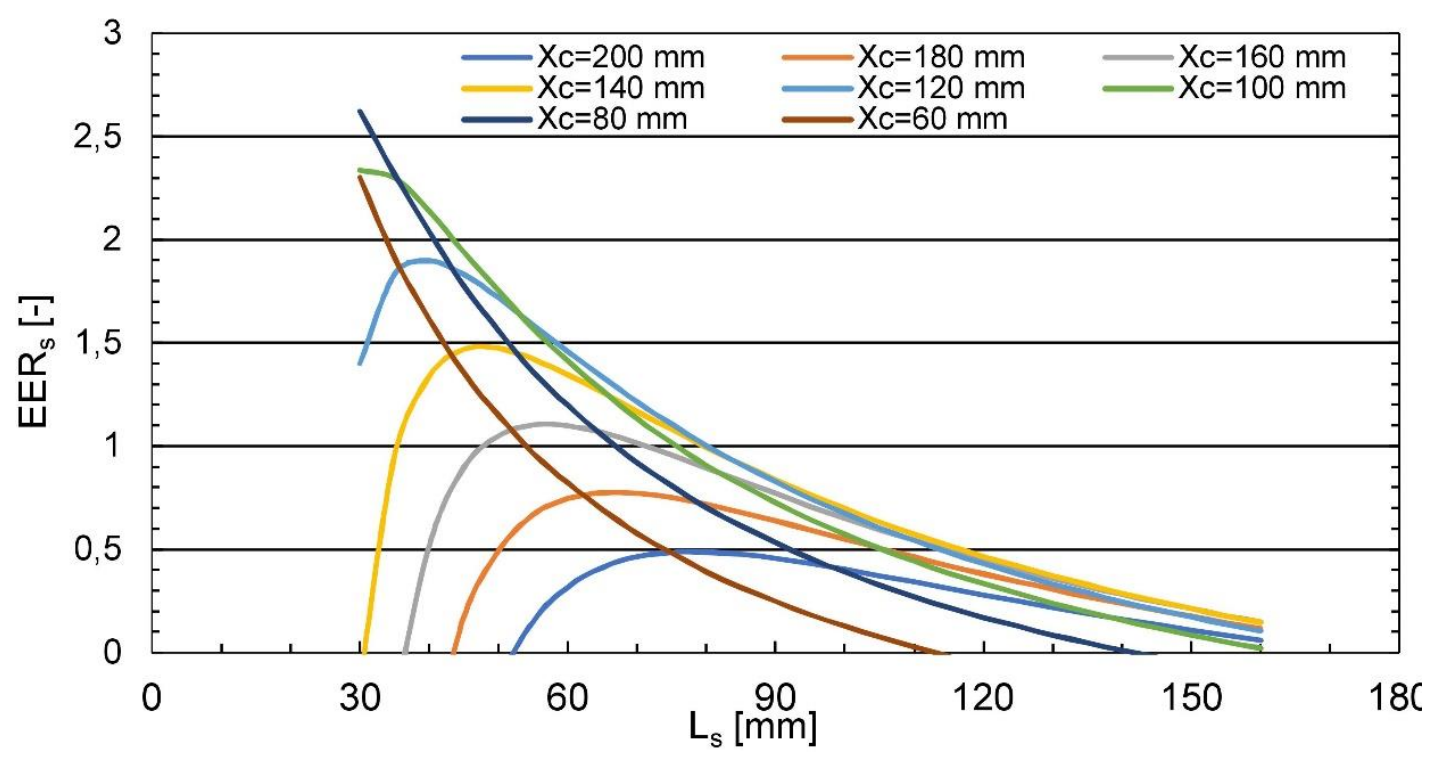


Rysunek 4.2: Współczynnik EER stosu w zależności od jego długości i położenia [38].

\section{Rezonator}

Rezonator to element, który jak sugeruje nazwa, zapewnia warunki rezonansu dla fali akustycznej. Izoluje on również pole akustyczne od otoczenia. Umieszcza się w nim wszystkie główne elementy urządzenia termoakustycznego - stos, wymienniki ciepła, źródło dźwięku. Jak pokazuje to Tabela 1 przekrój poprzeczny rezonatora najczęściej przybiera kształt okrągły, aczkolwiek zdarzają się także rozwiązania z rezonatorem prostokątnym. W celu minimalizacji start związanych z dyssypacją energii fali akustycznej wzdłuż ścian wewnętrznych długość rezonatora odpowiada zazwyczaj 1/4 lub 1/2 długości fali akustycznej. W przypadku pierwszej konstrukcji węzeł ciśnienia wypada na krańcu elementu, dlatego do pracy pod ciśnieniem różnym od atmosferycznego i z czynnikiem innym od powietrza wymaga on dodatkowego segmentu, tzw. bufora, który symuluje otwarty koniec (Rysunek 4.3 b). Hofler w [9] wykazał, że taki typ rezonatora może być dalej optymalizowany poprzez zmniejszenie średnicy części rezonatora znajdującego się za stosem. Minimum strat energii osiąga się dla stosunku średnic części rezonatora za stosem i części rezonatora, w której umieszczony jest stos równego 0.54 [39]. Przejście z części rezonatora o małej średnicy do bufora niejednokrotnie generuje straty wynikające $\mathrm{z}$ turbulencji. Z tego względu w obecnych konstrukcjach urządzeń o 1/4 długości fali akustycznej stosuje się bufory stożkowe $\mathrm{z}$ lagodnym przejściem [26] (Rysunek $4.3 \mathrm{~d}$ ).

Do pozostałych czynników, które uwzględnia się w czasie budowy rezonatora zalicza się jego właściwości mechaniczne, akustyczne i cieplne. Rezonator powinien odznaczać się określoną wytrzymałością mechaniczną pozwalającą na pracę przy wysokich ciśnieniach i stanowić sztywną granicę dla rozchodzącej się w nim fali akustycznej. Miarą takiego oporu jest impedancja akustyczna ośrodka, która proporcjonalna jest do gęstości czynnika. Z tych dwóch względów do najczęściej stosowanych materiałów zalicza się metale, a w szczególności stal nierdzewną. Do ich wad należy zaliczyć wysoki współczynnik przewodzenia ciepła, który zwiększa ilość ciepła wymienianego pomiędzy czynnikiem roboczym a otoczeniem. Wynikające $\mathrm{z}$ tego straty są znaczące zwłaszcza w rejonie stosu, którego krańce pracują przy temperaturach odmiennych od temperatury otoczenia. Dlatego ten odcinek rezonatora wykonuje się niejednokrotnie $\mathrm{z}$ odrębnego materiału, charakteryzującego się niskim współczynnikiem ciepła. 

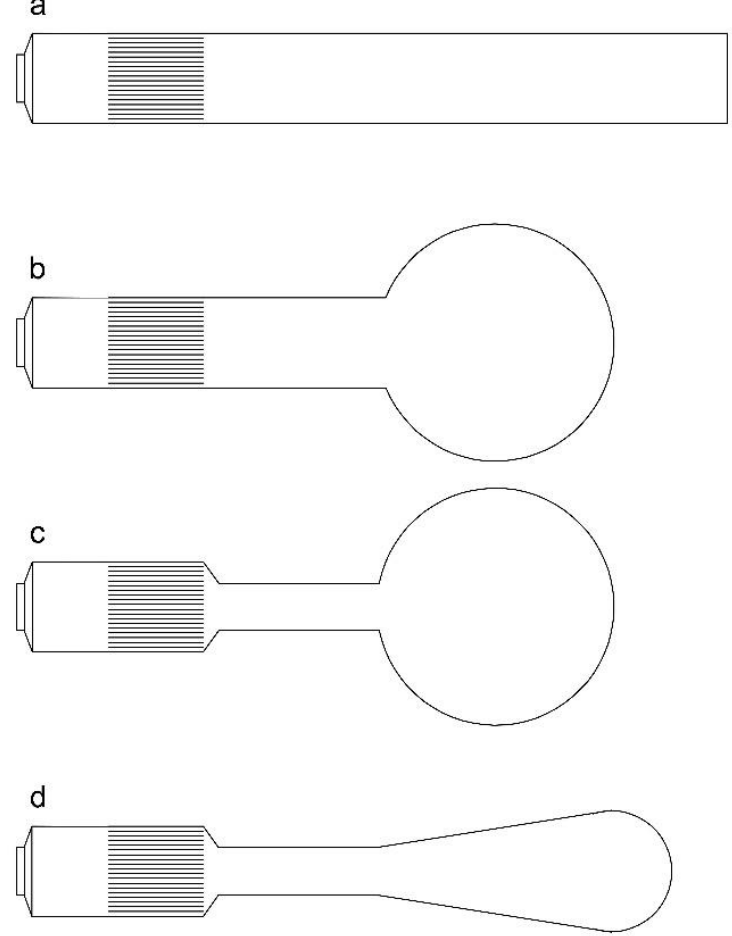

Rysunek 4.3: Rodzaje rezonatora: a) o długości połowy długości fali akustycznej, b) o długości jednej czwartej długości fali akustycznej z buforem kulistym, c) Hoflera o długości jednej czwartej długości fali akustycznej ze zmienną średnicą rezonatora, d) o długości jednej czwartej długości fali akustycznej z buforem stożkowym.

\section{Czynnik roboczy}

Swift w [10] wykazał, że wydajność urządzenia termoakustycznego jest proporcjonalna do iloczynu $p_{m} a A$, gdzie $p_{m}$ to średnie ciśnienie robocze panujące w rezonatorze, $a$ to prędkość dźwięku, zaś $A$ to pole przekroju rezonatora. Ośrodki o wysokiej prędkości rozchodzenia się dźwięku są zatem wskazane jako czynniki robocze, gdyż będą prowadzić do wzrostu wydajności. Czynniki te powinny się także charakteryzować wysoką wartością głębokości penetracji ciepła $\left(\delta_{k}=\sqrt{2 K / \rho c_{p} \omega}\right)$ i niską wartością głębokości penetracji lepkości $\left(\delta_{v}=\sqrt{2 \mu / \rho \omega}\right)$. Stosunek tych liczb ujęty jest w liczbie Prandtla, która jest bezwymiarową stałą materiałową niezależną od własności samego przepływu np. częstotliwości fali akustycznej. Dla niskiej liczby Prandtla termiczna warstwa przyścienna przeważa nad hydrauliczną warstwą przyścienną, a dyfuzja ciepła w płynie dominuje nad dyfuzją pędu [40]. Czynniki o niskiej liczbie Prandtla będą prowadzić więc do wzrostu ilość ciepła transportowanego pomiędzy płynem a płynem, a jednocześnie będą zmniejszać straty lepkościowe [41-43]. Substancje, które w największym stopniu spełniają powyższe wymagania należą do grupy gazów szlachetnych, i dlatego takie gazy jak hel czy argon są najczęściej stosowane w urządzeniach termoakustycznych [26]. W celu optymalizacji właściwości czynnika roboczego często bada się również mieszaniny gazów szlachetnych. Tijani i in. w swojej pracy [41] wykazali, że np. użycie mieszaniny helu i ksenonu z 30\% zawartością ksenonu prowadzi do $70 \%$ wzrostu współczynnika COP urządzenia w stosunku do czystego helu. Podobne wyniku uzyskano w analizie numerycznej [42], gdzie zmniejszenie 
liczby Prandtla z 0.7 dla czystego helu do 0.28 dla mieszaniny helu z ksenonem doprowadziło do wzrostu współczynnika COPR o 78\%.

W prostych, eksperymentalnych urządzeniach, które służą demonstracji zjawiska termoakustycznego mierzonego różnicą temperatur pomiędzy krańcami stosu najczęściej używanym czynnikiem roboczym jest powietrze (Tabela 1).

\section{Ciśnienie robocze i stosunek ciśnień}

W urządzeniach termoakustycznych znaczenie mają dwie wartości ciśnień, pierwsza dotyczy średniego ciśnienia panującego w rezonatorze, druga amplitudy ciśnienia w miejscu odpowiadającym strzałce ciśnienia. Wartości te opisuje się najczęściej przez jeden parametr stosunku ciśnień $-D R=p_{1} / p_{m}$. W celu uniknięcia nieliniowości zjawiska i turbulentnych struktur przepływu przyjmuje się taki stosunek DR, dla którego liczba Macha jest mniejsza od 0.1, a liczba Reynoldsa od 500 [39]. Zgodnie z badaniami prowadzonymi przez Piccolo A. i in [44] rozbieżności pomiędzy wynikami analitycznymi otrzymanymi na podstawie modelu liniowego, a wynikami eksperymentalnymi uzyskanymi $\mathrm{z}$ urządzenia pracującego z powietrzem pod ciśnieniem atmosferycznym i przy częstotliwości $200 \mathrm{~Hz}$ zaczynają pojawiać się już przy stosunku ciśnień równemu $2 \%$. Z kolei w przypadku prac prowadzonych przez Atchley A. nad urządzeń wypełnionym z helem pod ciśnieniem 1.14 bar pracującym z częstotliwością $696 \mathrm{~Hz}$ takie rozbieżności mogą się już pojawiać dla DR równego $1.1 \%$.

Wartość średniego ciśnienia jest ograniczona jedynie przez szczelność i wytrzymałość materiałów, z których zbudowany jest rezonator. Korzystne jest stosowanie możliwe wysokich ciśnień, gdyż zgodnie z przedstawioną wcześniej zależnością moc urządzenia rośnie wraz ze wzrostem ciśnienia średniego [10]. Z drugiej jednak strony wysokie ciśnienia będą prowadziły do stosów o małej porowatości, bowiem głębokość penetracji ciepła jest odwrotnie proporcjonalna do ciśnienia średniego. $Z$ tego względu wybór ciśnienia niejednokrotnie jest kompromisem uwzględniającym możliwości wykonania stosu. Wartości ciśnień nie przekraczają jednak najczęściej 20 bar (Tabela 1). W przypadku prostych urządzeń eksperymentalnych pracujących z powietrzem jako czynnikiem roboczym ciśnienie panujące w urządzeniu odpowiada ciśnieniu atmosferycznemu.

\section{Częstotliwość}

Gęstość mocy urządzenia termoakustycznego jest liniowo zależna od częstotliwości dźwięku [10], stąd wysokie wartości są pożądane. Z drugiej jednak strony częstotliwość dźwięku wpływa na porowatość stosu, gdyż głębokość penetracji ciepła jest odwrotnie proporcjonalna do pierwiastka z częstotliwości. Wybór odpowiedniej wartości jest najczęściej kompromisem wynikającym z żądanej mocy, rodzaju czynnika roboczego, konstrukcji rezonatora i możliwości wykonania podzespołów urządzenia takich jak stos czy wymienniki ciepła. Najczęściej częstotliwości pracy mieszczą się w zakresie od 100 do $700 \mathrm{~Hz}$ (Tabela 1).

\section{Podsumowanie}

Termoakustyczne urządzenia chłodnicze wykorzystują energię fali akustycznej do transportu ciepła z ośrodka o niskiej do ośrodka o wysokiej temperaturze. Urządzenia te posiadają szerokie perspektywy rozwoju, za czym przemawiają liczne zalety technologii termoakustycznej. Do głównej z nich należy zaliczyć pracę bez szkodliwych dla środowiska czynników chłodniczych, zaś do pozostałych prostą budowę, możliwości stosowania standardowych i łatwo dostępnych materiałów. Chłodnicze urządzenia termoakustyczne posiadają szerokie spektrum zastosowań. Mogą być wykorzystywane jako pompy ciepła do 
zastosowań domowych i komercyjnych, pompy ciepła zasilane ciepłem odpadowym, systemy chłodzenia elektroniki o małych wydajnościach, systemy do skraplania gazu czy kriogeniczne instalacje laboratoryjne. Ze względu na relatywnie niską sprawność urządzenia te nie są jednak postrzegane jako rozwiązanie alternatywne dla obecnych rozwiązań konwencjonalnych, a wciąż traktowane są jako rozwiązania perspektywiczne, które nadal wymagają wielu badań.

W artykule tym przedstawiono obecne kierunki prac prowadzonych nad urządzeniami termoakustycznymi. Przegląd przeprowadzonych prac skupiono głównie na badaniach eksperymentalnych $\mathrm{z}$ zakresu wyboru optymalnych parametrów konstrukcyjnych i eksploatacyjnych termoakustycznych urządzeń chłodniczych $z$ falą stojącą. W analizowanych pracach wpływ tych parametrów sprowadzał się najczęściej do wyznaczenia różnicy temperatur powstającej wzdłuż stosu, współczynnika COP/EER urządzenia bądź stosu lub wymaganej mocy akustycznej niezbędnej do otrzymania żądanego efektu chłodniczego. Elementem, który najczęściej badano był stos, jego geometria, położenie, długość i materiał, $\mathrm{z}$ którego jest zbudowany. Z rozważnych prac wynikają następujące wnioski: stos powinien być tak skonstruowany, aby warstwa przyścienna, w której występuje zjawisko termoakustyczne była jak największa; długość i położenie stosu są to dwie zmienne zależne od siebie i w czasie optymalizacji powinny być razem analizowane; Mylar to materiał, który najczęściej jest wykorzystywany do budowy stosu; gazy szlachetne i mieszaniny gazów szlachetnych to substancje, które najlepiej odpowiadają wymaganiom stawianym czynnikom roboczym urządzeń termoakustycznych; częstotliwość i ciśnienie robocze to zmienne, które stanowią parametry początkowe dla projektowania urządzenia i wyboru dalszych rozwiązań. 
Tabela 1: Przegląd badań eksperymentalnych.

\begin{tabular}{|c|c|c|c|c|c|c|c|c|c|c|c|}
\hline $\begin{array}{l}\vec{y} \\
0 \\
0 \\
0 \\
3\end{array}$ & 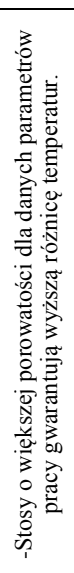 & 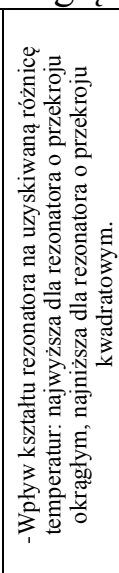 & 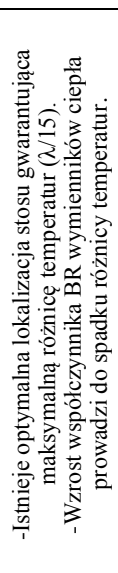 & 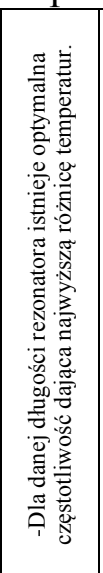 & 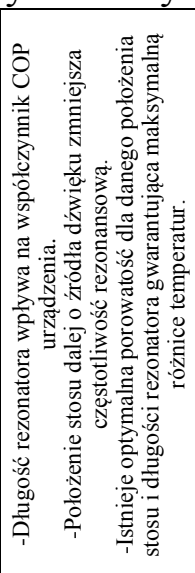 & 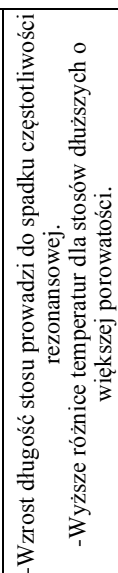 & 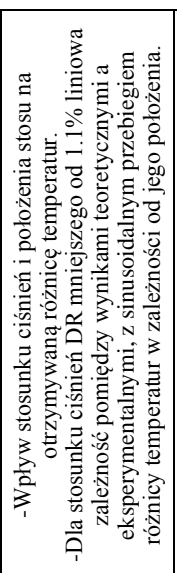 & 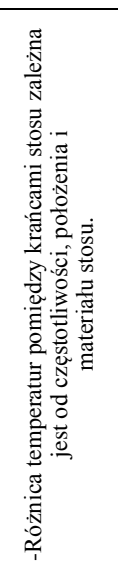 & 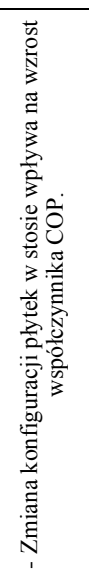 & 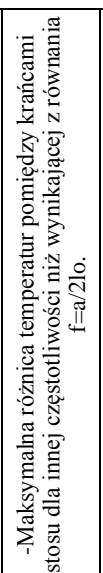 & 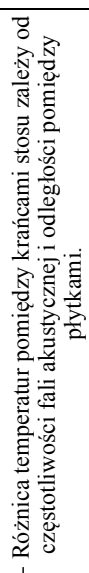 \\
\hline 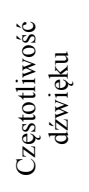 & $\begin{array}{l}\text { 포 } \\
\text { 守 }\end{array}$ & 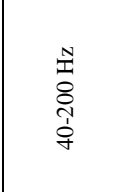 & $\begin{array}{l}\text { N } \\
\text { D } \\
\text { on }\end{array}$ & 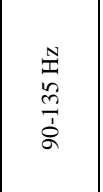 & 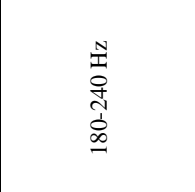 & $\begin{array}{l}\text { 송 } \\
8 \\
0 \\
0 \\
0\end{array}$ & $\begin{array}{l}\text { 순 } \\
\text { ه్ }\end{array}$ & 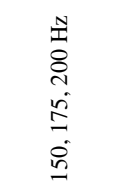 & 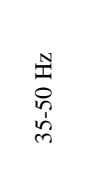 & 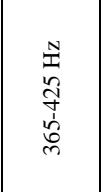 & 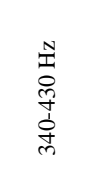 \\
\hline 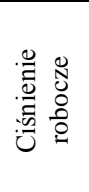 & 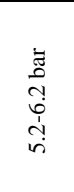 & 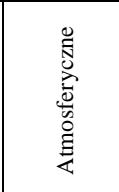 & 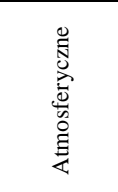 & 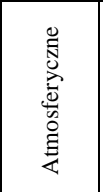 & 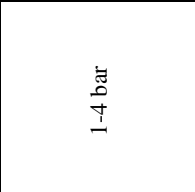 & 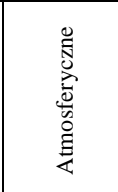 & 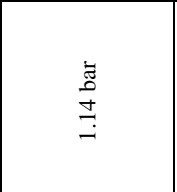 & 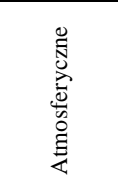 & 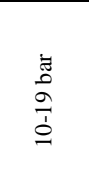 & 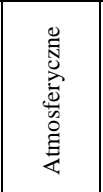 & 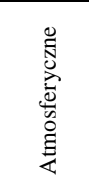 \\
\hline 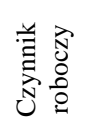 & ఖ & 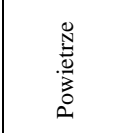 & $\begin{array}{l}: \\
\stackrel{\Xi}{0} \\
: \\
:\end{array}$ & 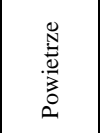 & 零 & 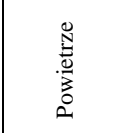 & 品 & 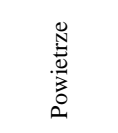 & 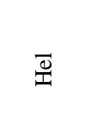 & 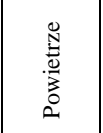 & 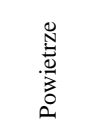 \\
\hline 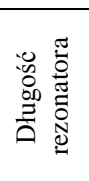 & , & & $\begin{array}{l}\text { ह } \\
\vdots \\
\vdots\end{array}$ & $\begin{array}{l}\text { : } \\
\vdots \\
\vdots \\
\vdots\end{array}$ & 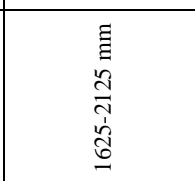 & 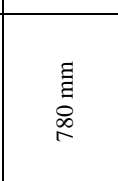 & 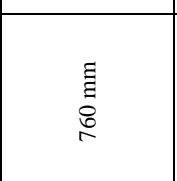 & & 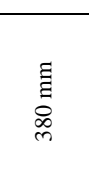 & 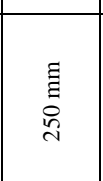 & 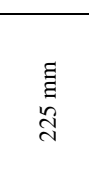 \\
\hline 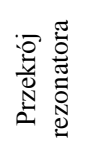 & $\begin{array}{l}\text { 勇 } \\
\text { 音 }\end{array}$ & 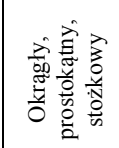 & 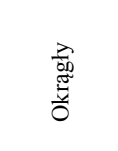 & $\begin{array}{l}\text { 总 } \\
\text { 咅 }\end{array}$ & $\begin{array}{l}\text { 㷰 } \\
\frac{\tilde{y}}{0}\end{array}$ & $\begin{array}{l}\text { 总 } \\
\text { 咅 }\end{array}$ & $\begin{array}{l}\text { 咅 } \\
\text { 章 }\end{array}$ & $\begin{array}{l}\text { 总 } \\
\text { 音 }\end{array}$ & 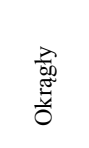 & 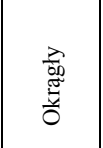 & $\begin{array}{l}\text { 总 } \\
\text { 竞 }\end{array}$ \\
\hline 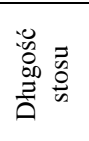 & , & & 吾 & & 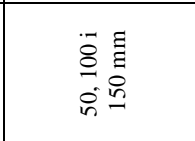 & 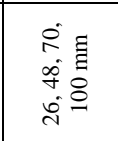 & 竞 & & 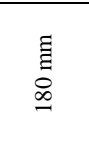 & 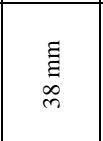 & 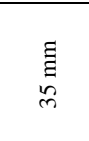 \\
\hline 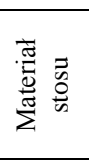 & 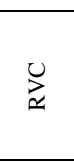 & 营 & $\sum_{\bar{z}}^{\frac{\vec{m}}{2}}$ & 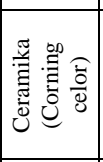 & 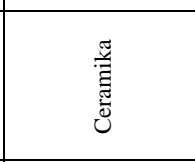 & 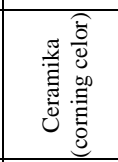 & 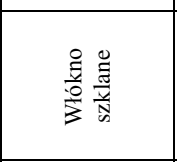 & 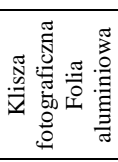 & 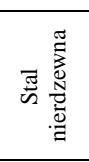 & 部 & 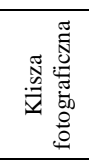 \\
\hline 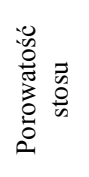 & 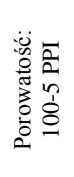 & & 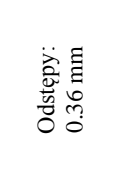 & 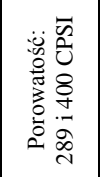 & 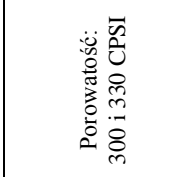 & 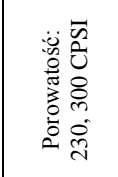 & 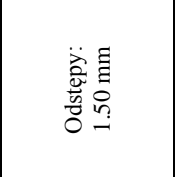 & 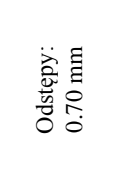 & 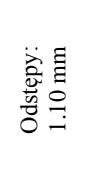 & 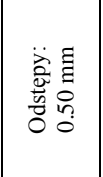 & 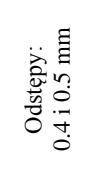 \\
\hline
\end{tabular}




\begin{tabular}{|c|c|c|c|c|c|}
\hline 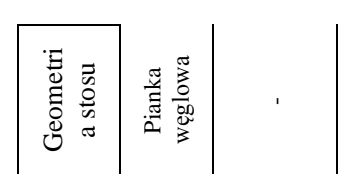 & $\begin{array}{ll}1 \\
1\end{array}$ & & 1 & 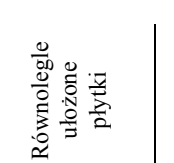 & \\
\hline 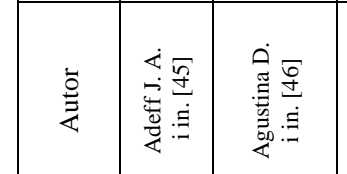 & 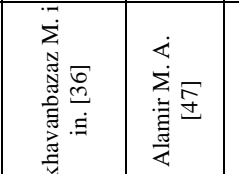 & & & 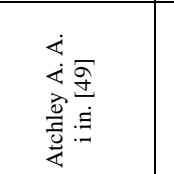 & \\
\hline
\end{tabular}

\begin{tabular}{|c|c|c|c|c|c|c|c|c|c|c|}
\hline 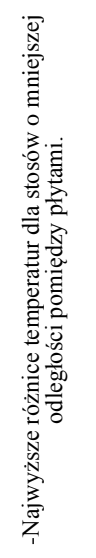 & 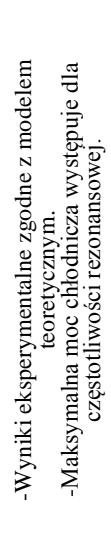 & 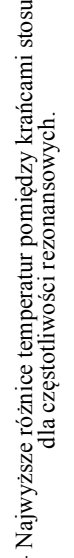 & 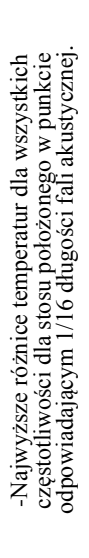 & 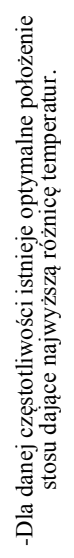 & 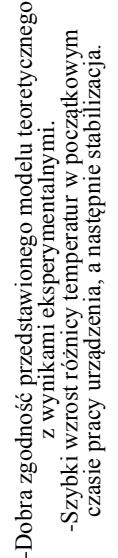 & 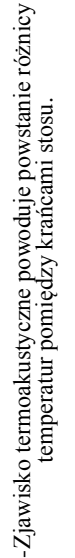 & 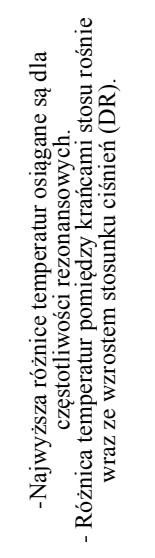 & 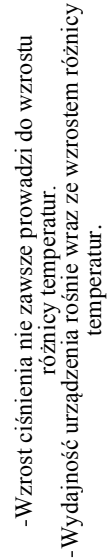 & 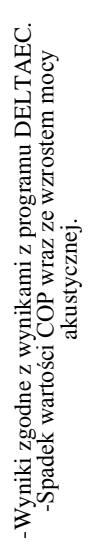 & 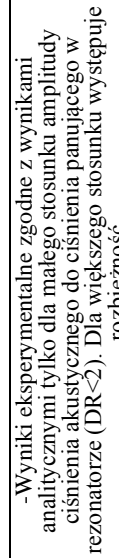 \\
\hline 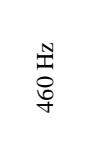 & $\begin{array}{l}\text { N } \\
20 \\
0 \\
0 \\
0\end{array}$ & $\begin{array}{l}\text { Nàn } \\
0 \\
0 \\
0 \\
0\end{array}$ & 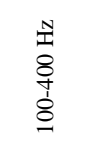 & 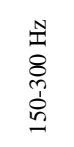 & $\begin{array}{l}\text { 솟 } \\
\text { \& }\end{array}$ & \begin{tabular}{l} 
N \\
\multirow{2}{\alpha}{}
\end{tabular} & 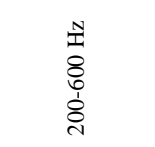 & 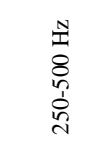 & $\begin{array}{l}\text { 퐁 } \\
\stackrel{9}{I}\end{array}$ & $\begin{array}{l}\text { 손 } \\
\text { : }\end{array}$ \\
\hline 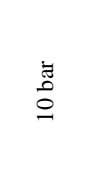 & ' & 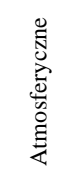 & 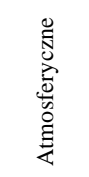 & 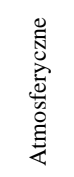 & 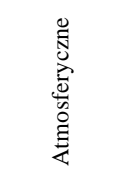 & పี & $\begin{array}{l}\text { 总 } \\
\stackrel{0}{a} \\
\text { i }\end{array}$ & 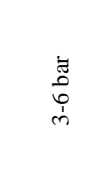 & $\begin{array}{l}\text { 总 } \\
\text { aे }\end{array}$ & 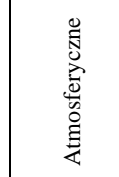 \\
\hline ల & & 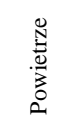 & 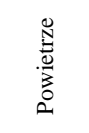 & 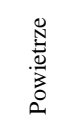 & 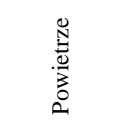 & 㞼 & 导 & $\Phi$ & 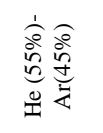 & 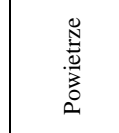 \\
\hline 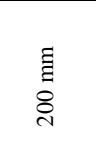 & 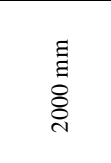 & 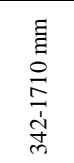 & 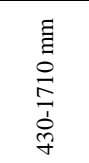 & & $\begin{array}{l}\text { 音 } \\
\text { 总 }\end{array}$ & 言 & 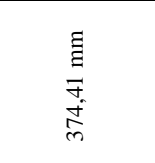 & & 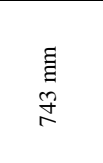 & $\begin{array}{l}\text { 音 } \\
\text { d. } \\
\infty\end{array}$ \\
\hline $\begin{array}{l}\frac{x}{\mathrm{~g}} \\
\frac{\mathrm{g}}{\mathrm{y}} \\
\frac{\mathrm{y}}{0}\end{array}$ & 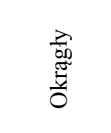 & 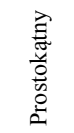 & 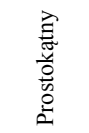 & 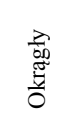 & 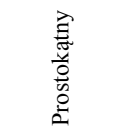 & $\begin{array}{l}\frac{3}{\mathrm{~g}} \\
\frac{\mathrm{g}}{\mathrm{y}}\end{array}$ & $\begin{array}{l}\frac{x}{\mathrm{~g}} \\
\frac{\mathrm{g}}{\mathrm{y}} \\
\frac{\mathrm{y}}{0}\end{array}$ & 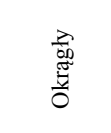 & 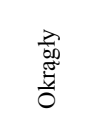 & 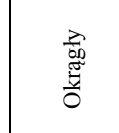 \\
\hline 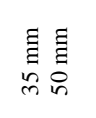 & $\begin{array}{l}\text { 音 } \\
\stackrel{0}{0}\end{array}$ & 声 & 声 & $\underset{m}{\stackrel{\Xi}{g}}$ & 言 & 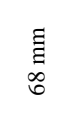 & $\begin{array}{l}\text { E } \\
\vdots \\
n \\
o \\
o\end{array}$ & $\underset{\infty}{\Xi}$ & 㽦 & 志 \\
\hline 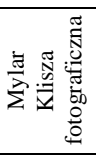 & $\frac{\vec{m}}{\sum_{2}^{2}}$ & 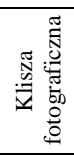 & 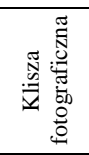 & Uू & Uू & $\frac{\underline{z}}{2}$ & 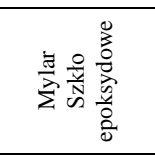 & $\begin{array}{l}\frac{.}{0} \\
\frac{\sigma_{0}^{2}}{2}\end{array}$ & $\begin{array}{l}\overline{0} \\
\frac{0}{0} \\
\frac{0}{0} \\
2\end{array}$ & $\begin{array}{l}\frac{\overline{0}}{2} \\
\frac{0}{0} \\
\frac{0}{0} \\
2\end{array}$ \\
\hline 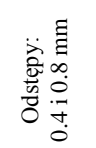 & 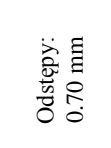 & 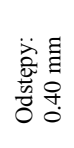 & 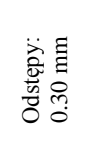 & 鄫 & 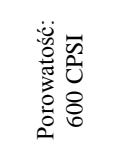 & 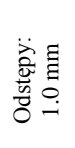 & 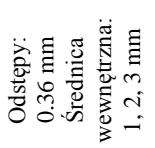 & 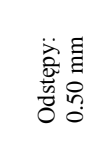 & 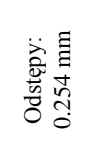 & 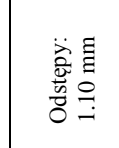 \\
\hline
\end{tabular}




\begin{tabular}{|c|c|c|c|c|c|c|}
\hline 翌 & & & 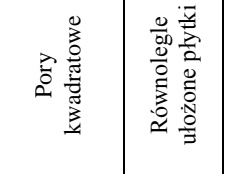 & 1 & & \\
\hline 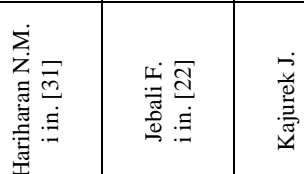 & 憝 & & 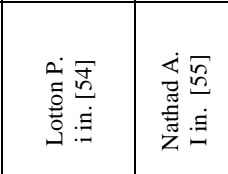 & 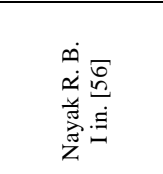 & & \\
\hline
\end{tabular}

\begin{tabular}{|c|c|c|c|c|c|c|c|c|}
\hline 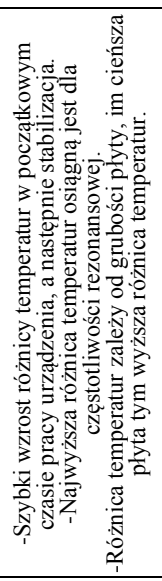 & 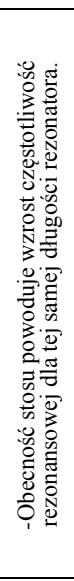 & 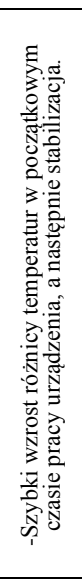 & 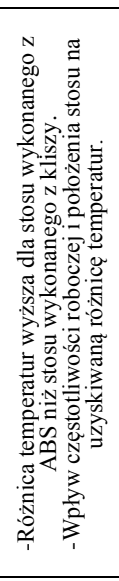 & 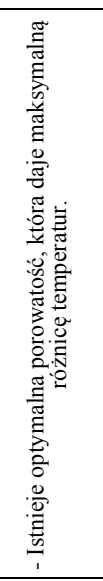 & 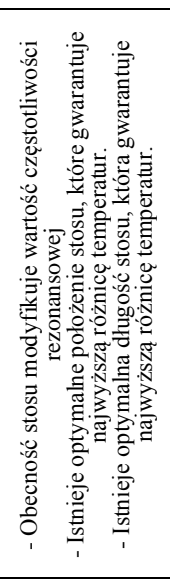 & 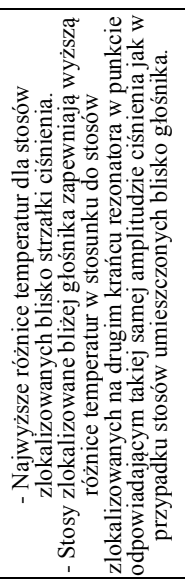 & 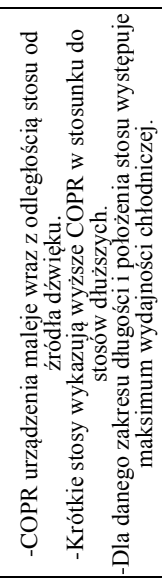 & 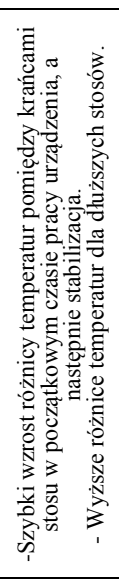 \\
\hline $\begin{array}{l}\text { Nㅗㅇ } \\
\stackrel{0}{0}\end{array}$ & 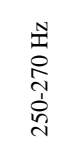 & 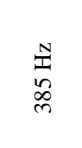 & 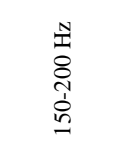 & $\begin{array}{l}\text { त्र } \\
0 \\
0 \\
\stackrel{0}{-} \\
\stackrel{5}{0}\end{array}$ & 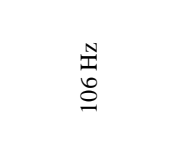 & 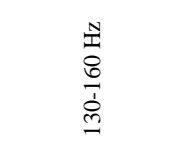 & 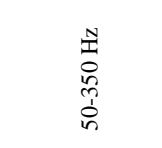 & 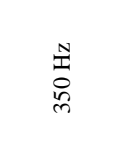 \\
\hline 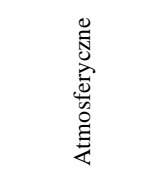 & 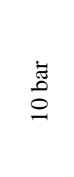 & 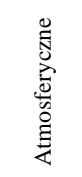 & 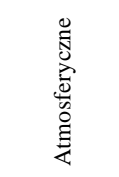 & 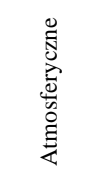 & 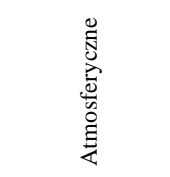 & 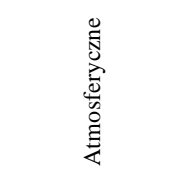 & 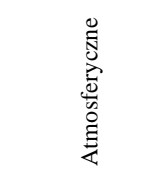 & 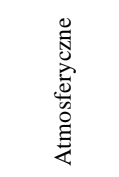 \\
\hline 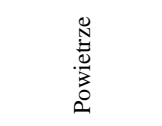 & 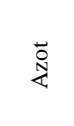 & 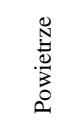 & 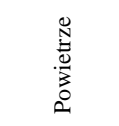 & 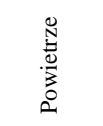 & $\begin{array}{l}\tilde{N} \\
\stackrel{0}{0} \\
\bar{z} \\
0 \\
0\end{array}$ & 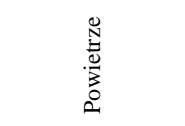 & 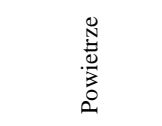 & 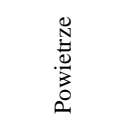 \\
\hline $\begin{array}{l}\text { 志 } \\
\stackrel{+}{\sigma}\end{array}$ & 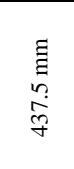 & 声 & 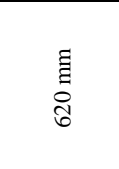 & 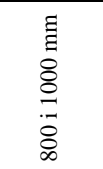 & $\begin{array}{l}\text { 音 } \\
\stackrel{8}{\circ}\end{array}$ & 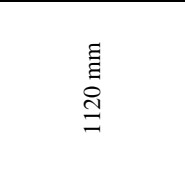 & 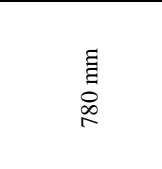 & 吾 \\
\hline 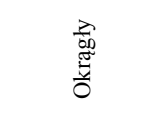 & 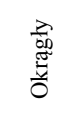 & 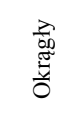 & 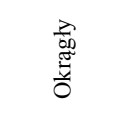 & 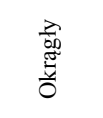 & 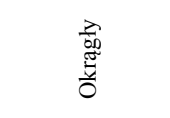 & $\begin{array}{l}\text { 晜 } \\
\text { 竞 }\end{array}$ & 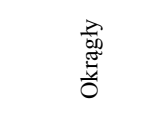 & $\begin{array}{l}\text { 㚟 } \\
\text { 행 }\end{array}$ \\
\hline $\begin{array}{l}5 \\
\end{array}$ & $\begin{array}{l}\text { 吉 } \\
\text { 品 }\end{array}$ & 志 & & $\begin{array}{l}\tilde{E} \\
\stackrel{\Xi}{8}\end{array}$ & $\begin{array}{l}\text { 音 } \\
\frac{0}{0} \\
\frac{1}{d}\end{array}$ & 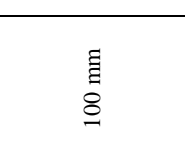 & 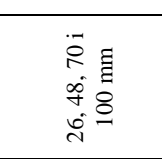 & 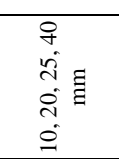 \\
\hline 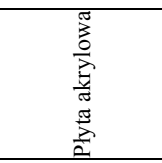 & & 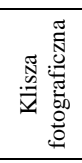 & 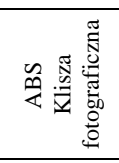 & 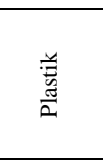 & $\frac{g}{\frac{g}{2}}$ & $\begin{array}{l}\frac{.}{\bar{*}} \\
\frac{\pi}{2}\end{array}$ & 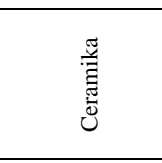 & 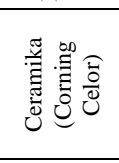 \\
\hline 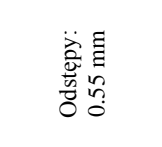 & 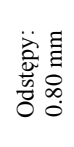 & 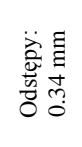 & 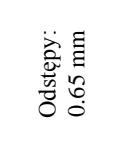 & 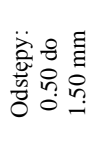 & 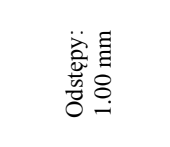 & 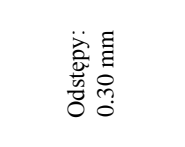 & 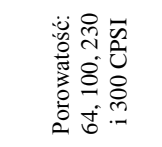 & 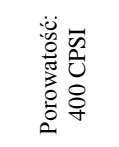 \\
\hline
\end{tabular}




\begin{tabular}{|c|c|c|c|c|c|c|c|c|}
\hline 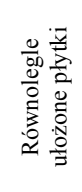 & 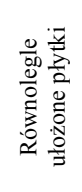 & $\begin{array}{l}\text { 高 } \\
\text { 离 } \\
\text { की }\end{array}$ & 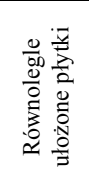 & 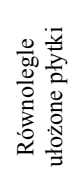 & 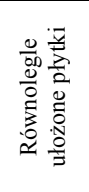 & 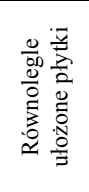 & 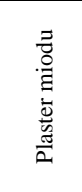 & 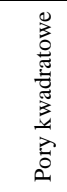 \\
\hline 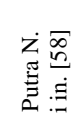 & 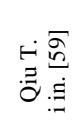 & 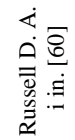 & 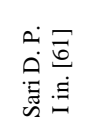 & 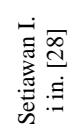 & 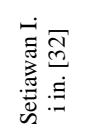 & 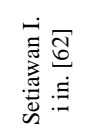 & 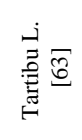 & 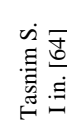 \\
\hline
\end{tabular}

\begin{tabular}{|c|c|c|c|c|c|c|c|c|}
\hline 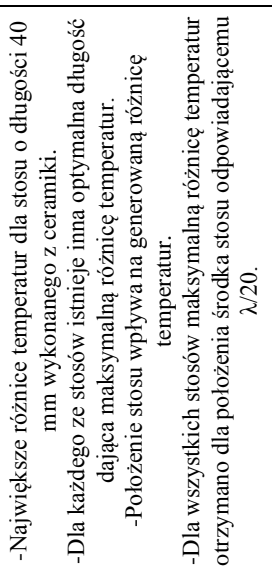 & 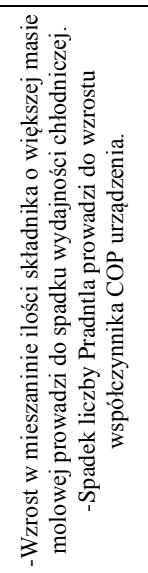 & 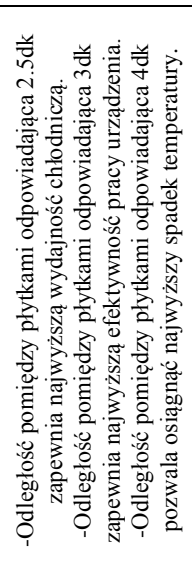 & 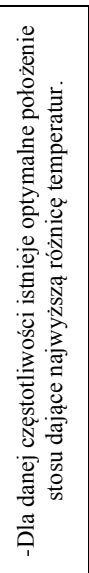 & 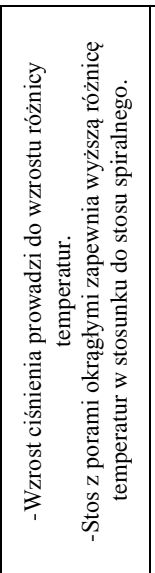 & 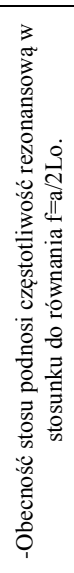 & 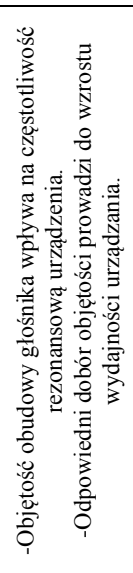 & 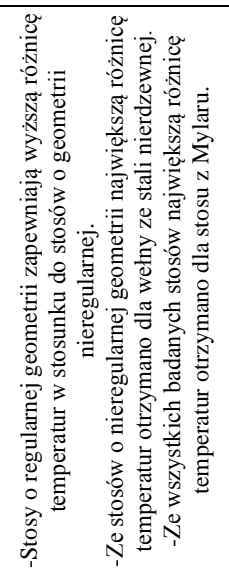 & 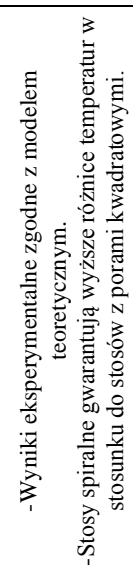 \\
\hline $\begin{array}{l}\text { N } \\
\text { D } \\
\text { d }\end{array}$ & ' & $\begin{array}{l}\text { 종 } \\
\text { Oे+ }\end{array}$ & $\begin{array}{l}\text { N } \\
\text { 亲 } \\
\text { 足 }\end{array}$ & 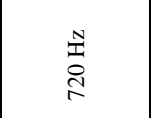 & \begin{tabular}{l} 
N \\
\multirow{2}{*}{} \\
8 \\
0 \\
8
\end{tabular} & 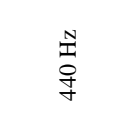 & $\underset{N}{N}$ & $\begin{array}{l}\text { 종 } \\
\text { Oे }\end{array}$ \\
\hline 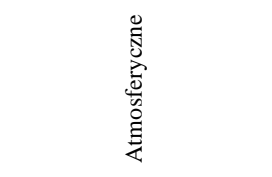 & 总 & 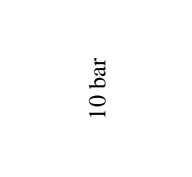 & 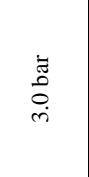 & 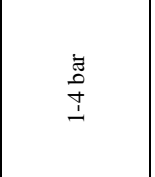 & 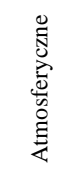 & 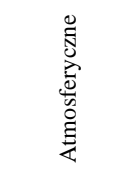 & 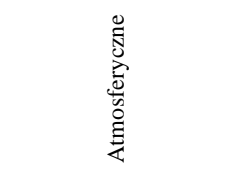 & 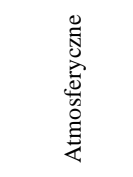 \\
\hline $\begin{array}{l}: \\
: \\
: \\
:\end{array}$ & 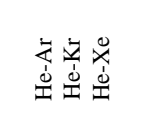 & 焉 & 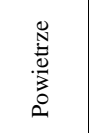 & 零 & 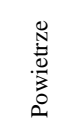 & 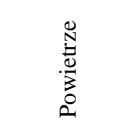 & 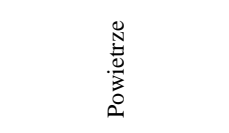 & $\begin{array}{l}: \\
: \\
: \\
:\end{array}$ \\
\hline $\begin{array}{l}\text { 音 } \\
\text { 京 }\end{array}$ & 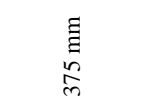 & 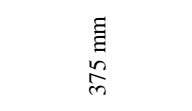 & $\frac{\tilde{y}}{0}$ & 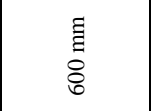 & 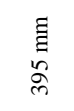 & ' & $\begin{array}{l}\text { 諳 } \\
\stackrel{\infty}{\infty}\end{array}$ & $\stackrel{\Xi}{\stackrel{\Xi}{\Delta}}$ \\
\hline $\begin{array}{l}\frac{7}{c 0} \\
\frac{0}{\tilde{g}} \\
\frac{\pi}{0}\end{array}$ & 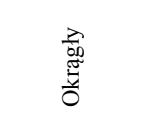 & 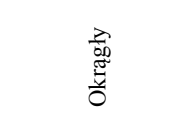 & 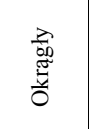 & 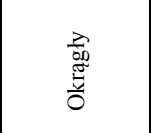 & 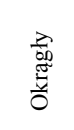 & 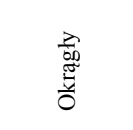 & 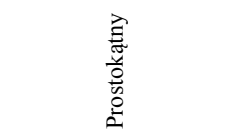 & 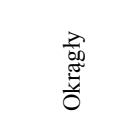 \\
\hline 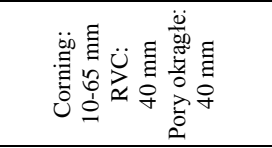 & $\begin{array}{l}\Xi \\
\vdots \\
\infty \\
\infty\end{array}$ & $\underset{\infty}{\mathbb{E}}$ & $\underset{\mathrm{I}}{\mathrm{I}}$ & క్ & 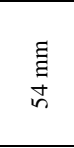 & 离 & ' & 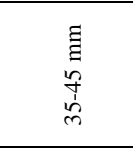 \\
\hline 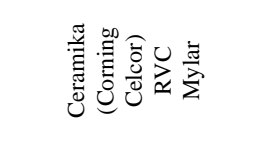 & 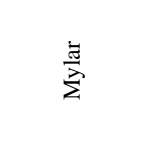 & 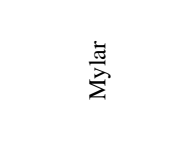 & 装 & 童足 & 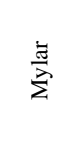 & 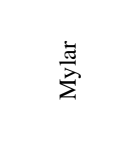 & 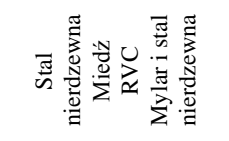 & 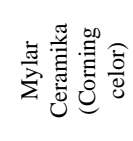 \\
\hline 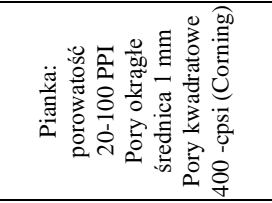 & 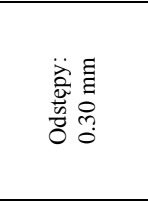 & 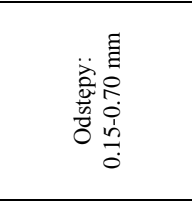 & 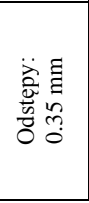 & 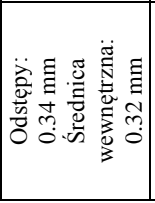 & & 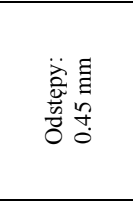 & & 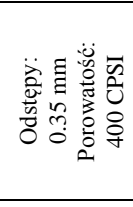 \\
\hline
\end{tabular}




\begin{tabular}{|c|c|c|c|c|c|c|c|c|}
\hline 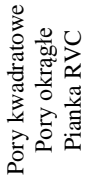 & 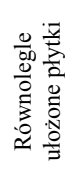 & 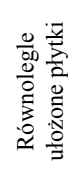 & 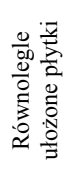 & 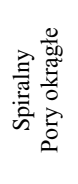 & 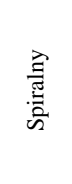 & $\begin{array}{l}\text { 窇 } \\
\text { 离 } \\
\text { की }\end{array}$ & 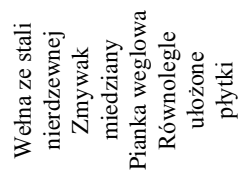 & 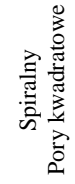 \\
\hline $\begin{array}{l}\dot{\infty} \\
\stackrel{\Xi}{\Xi} \\
\dot{\bar{g}} \\
\stackrel{\Xi}{\oplus}\end{array}$ & 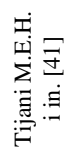 & 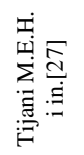 & 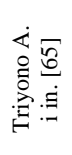 & 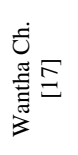 & 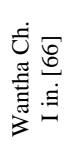 & 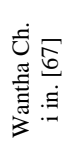 & 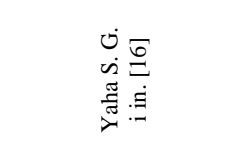 & 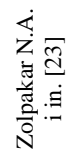 \\
\hline
\end{tabular}

\section{Bibliografia:}

[1] C. Herman and Z. Travnicek, Cool sound: The future of refrigeration? Thermodynamic and heat transfer issues in thermoacoustic refrigeration, Heat Mass Transf., vol. 42, no. 6, pp. 492-500, 2006.

[2] N. Rott, Thermoacoustics, Adv. Appl. Mech., vol. 20, pp. 135-175, Jan. 1980.

[3] A. A. Putnam and W. R. Dennis, Survey of Organ-Pipe Oscillations in Combustion Systems, J. Acoust. Soc. Am., vol. 28, no. 2, pp. 246-259, 1956.

[4] K. T. Feldman, Review of the literature on Sondhauss thermoacoustic phenomena, J. Sound Vib., vol. 7, no. 1 , pp. 71-82, 1968.

[5] G. Bisio and G. Rubatto, Sondhauss and Rijke oscillations - thermodynamic analysis, possible applications and analogies, Enery, vol. 24, pp. 117-131, 1999.

[6] W. S. Rayleigh, Theory of Sound, London Macmillan, Repr. 1945, New York Dover, 1896.

[7] T. Jin, J. Huang, Y. Feng, R. Yang, K. Tang and R. Radebaugh, Thermoacoustic prime movers and refrigerators: Thermally powered engines without moving components, Energy, vol. 93, pp. 828-853, 2015.

[8] J. Wheatley, T. Hofler, G. W. Swift and A. Migliori, Understanding some simple phenomena in thermoacoustics with applications to acoustical heat engines, Am. J. Phys., vol. 53, no. 2, pp. 147-162, 1985.

[9] T. J. Hofler, Thermoacoustic refrigerator design and performance, Ph.D. disseration, Physics Department, University of California, San Diego, 1986.

[10]G. W. Swift, Thermoacoustic engines, J. Acoust. Soc. Am., vol. 84, no. 4, pp. 1145-1180, 1988.

[11]J. H. Xiao, Thermoacoustic heat transportation and energy transformation Part 1: Formulation of the problem, Cryogenics, vol. 35, no. 1, pp. 15-19, 1995.

[12]H. Babaei and K. Siddiqui, Design and optimization of thermoacoustic devices, Energy Convers. Manag., vol. 49, no. 12, pp. 3585-3598, 2008.

[13]S. L. Garrett, Thermoacoustic engines and refrigerators, AIP Conf. Proc., vol. 1440, no. 2004, pp. 9-22, 2012.

[14]THATEA: THermoAcoustic Technolofy for Energy Applications, Collaborative Project EP7ENERGY-2008-FET, Energy research Centre of the Netherlands, 2009-2012.

[15]S. H. Tasnim, S. Mahmud and R. A. Fraser, Compressible pulsating convection through regular and random porous media: The thermoacoustic case, Heat Mass Transf., vol. 48, no. 2, pp. 329-342, 2012.

[16]S. G. Yahya, X. Mao and A. J. Jaworski, Experimental investigation of thermal performance of random stack materials for use in standing wave thermoacoustic refrigerators, Int. J. Refrig., vol. 75, pp. 52-63, 2017.

[17]C. Wantha, The impact of stack geometry and mean pressure on cold end temperature of stack in thermoacoustic refrigeration systems, Heat and Mass Transf. vol. 54, no. 7, pp. 2153-2161, 2018.

[18]M. Wetzel and C. Herman, Design optimization of thermoacoustic refrigerators, Int. J. Refrig., vol. 20, no. 1, pp. 3-21, 1997.

[19]A. C. Alcock, L. K. Tartib, and T. C. Jen, Experimental investigation of an adjustable thermoacoustically-driven thermoacoustic refrigerator, Int. J. Refrig., vol. 94, pp. 71-86, 2018.

[20]I. Paek, L. Mongeau and J. E. Braun, Performance characterization of a small-capacity thermoacoustic cooler for air-conditioning applications, J. Mech. Sci. Technol., vol. 24, no. 9, pp. 1781-1791, 2010.

[21]M. E. H. Tijani, J. C. H. Zeegers, and A. T. A. M. De Waele, Construction and performance of a thermoacoustic refrigerator, Cryogenics, vol. 42, no. 1, pp. 59-66, 2002.

[22]F. Jebali, J. V. Lubiez and M. X. François, Response of a thermoacoustic refrigerator to the variation of the driving frequency and loading, Int. J. Refrig., vol. 27, no. 2, pp. 165-175, 2004.

[23]N. A. Zolpakar, N. Mohd-Ghazali and R. Ahmad, Experimental investigations of the performance of a standing wave thermoacoustic refrigerator based on multi-objective genetic algorithm optimized parameters, Appl. Therm. Eng., vol. 100, pp. 296-303, 2016.

[24]H. Chaitou and P. Nika, Exergetic optimization of a thermoacoustic engine using the particle swarm 
optimization method, Energy Convers. Manag., vol. 55, pp. 71-80, 2012.

[25]R. V. Rao, K. C. More, J. Taler and P. Ocłoń, Multi-objective optimization of thermo-acoustic devices using teaching-learning-based optimization algorithm, Sci. Technol. Built Environ., vol. 23, no. 8, pp. 12441252, Nov. 2017.

[26]N. A. Zolpakar, N. Mohd-Ghazali and M. Hassan El-Fawal, Performance analysis of the standing wave thermoacoustic refrigerator: A review, Renew. Sustain. Energy Rev., vol. 54, pp. 626-634, 2016.

[27]M. E. H. Tijani, J. C. H. Zeegers and A. T. A. M. de Waele, The optimal stack spacing for thermoacoustic refrigeration, J. Acoust. Soc. Am., vol. 112, no. 1, pp. 128-133, 2002.

[28]I. Setiawan, A. Bambang Setio Utomo M. Katsuta and M. Nohtomi, Experimental study on the influence of the porosity of parallel plate stack on the temperature decrease of a thermoacoustic refrigerator, J. Phys. Conf. Ser., vol. 423, no. 1, 2013.

[29]A. W. Avent and C. R. Bowen, Principles of thermoacoustic energy harvesting, Eur. Phys. J. Spec. Top., vol. 224, no. 14-15, pp. 2967-2992, 2015.

[30]J. Bosel, C. Trepp and J. G. Fourie, An alternative stack arrangement for thermoacoustic heat pumps and refrigerators, J. Acoust. Soc. Am., vol. 106, no. 2, pp. 707-715, 1999.

[31]N. M. Hariharan, P. Sivashanmugam and S. Kasthurirengan, Experimental investigation of a thermoacoustic refrigerator driven by a standing wave twin thermoacoustic prime mover, Int. J. Refrig., vol. 36, no. 8, pp. 2420-2425, 2013.

[32]I. Setiawan and A. B. Setia-Utomo, The Influence of the Length and Position of the Stack on the Performance of a Thermoacoustic Refrigerator, Disseration, Gadjah Mada Univesrity, Indonesia, 2013.

[33]G. W. Swift, Thermoacoustics: A Unifying Perspective for Some Engines and Refrigerators, J. Acoust. Soc. Am., vol. 113, no. 5, pp. 2379-2381, 2003.

[34]M. El Hassan Tijani, Loudspeaker-driven thermo-acousic refrigeration, Ph.D. disseration, Eindhoven University of Technoloy, The Netherlands, 2001.

[35]J. Kajurek, A. Rusowicz and A. Grzebielec, The Influence of Stack Position and Acoustic Frequency on the Performance of Thermoacoustic Refrigerator with the Standing Wave, Arch. Thermodyn., vol. 38, no. 4, pp. 89-107, 2017.

[36]M. Akhavanbazaz, M. H. K. Siddiqui and R. B. Bhat, The impact of gas blockage on the performance of a thermoacoustic refrigerator, Exp. Therm. Fluid Sci., vol. 32, no. 1, pp. 231-239, 2007.

[37]Y. T. Kim, M. G. Kim and S. J. Suh, Optimum Positions of a Stack in a Thermoacoustic Heat Pump, J. Korean Phys. Soc., vol. 36, no. 5, pp. 279-286, 2000.

[38]J. Kajurek, A. Rusowicz and A. Grzebielec, Design and simulation of a small capacity thermoacoustic refrigerator, SN Appl. Sci., no. 1:579, 2019.

[39]M. E. H. Tijani, J. C. H. Zeegers, and A. T. A. M. De Waele, Design of thermoacoustic refrigerators, Cryogenics, vol. 42, no. 1, pp. 49-57, 2002.

[40]Y. A. Cengel and A. M. Boles, Thermodynamics - An Engineering Approach, 5th Edition, McGrawHill, 2006.

[41]M. E. H. Tijani, J. C. H. Zeegers and A. T. A. M. de Waele, Prandtl number and thermoacoustic refrigerators, J. Acoust. Soc. Am., vol. 112, no. 1, pp. 134-143, 2002.

[42]S. H. Tasnim, S. Mahmud and R. A. Fraser, Effects of variation in working fluids and operating conditions on the performance of a thermoacoustic refrigerator, Int. Commun. Heat Mass Transf., vol. 39, no. 6, pp. 762-768, 2012.

[43]J. R. Belcher, W. V. Slaton, R. Raspet, H. E. Bass and J. Lightfoot, Working gases in thermoacoustic engines, J. Acoust. Soc. Am., vol. 105, no. 5, pp. 2677-2684, 1999.

[44]A. Piccolo and G. Cannistraro, Convective heat transport along a thermoacoustic couple in the transient regime, Int. J. Therm. Sci., vol. 41, no. 11, pp. 1067-1075, 2002.

[45]J. A. Adeff, T. J. Hofler, A. A. Atchley and W. C. Moss, Measurements with reticulated vitreous carbon stacks in thermoacoustic prime movers and refrigerators, vol. 104, no. 1, pp. 32-38, 1998.

[46]D. Agustina and S. Purnama, Experimental investigation on the effect of resonator shapes on the temperature characteristic of thermoacoustic cooling device, IOP Conf. Series: Materials Science and Engineering, vol. 539, no. 1, pp. 1-6, 2019.

[47]M. A. Alamir, Experimental study of the stack geometric parameters effect on the resonance frequency of a standing wave thermoacoustic refrigerator, Int. J. of Green Energy, vol. 16, no. 8, pp. 639-651, 2019.

[48] A.C. Alock, L.K. Tartibu and T.C. Jen, Experimental Investigation of Ceramic Substrates in Standing Wave Thermoacoustic Refrigerator, Procedia Manufacturing, vol. 7, pp. 79-85, 2017.

[49]A. A. Atchley, T. J. Hofler, M. L. Muzzerall, M. D. Kite and C. Ao, Acoustically generated temperature gradients in short plates, J. Acoust. Soc. Am., vol. 88, no. 1, pp. 251-263, 1990.

[50]K. A. Babu and P. Sherjin, Experimental investigations of the performance of a thermoacoustic refrigerator based on the Taguchi method, J. of Mech. Sci. and Tech., vol. 32, no. 2, pp. 929-935, 2018.

[51]B. Chen, Y. A. Abakr and M. Al-atabi, Investigation of an atmospheric pressure thermoacoustic cooling system by varying its operating frequency, J. of Eng. Sci. and Tech., vol. 8, no. 3, pp. 364-371, 2013. 
[52]G. Allesina, An experimental analysis of a stand-alone standing-wave thermoacoustic refrigerator, Int. J. Energy Environ. Eng., vol. 5, no. 1, pp. 1-9, 2014.

[53]J. Kajurek and A. Rusowicz, Performance analysis of the thermoacoustic refrigerator with the standing wave and air as a working fluid, E3S Web of Conferences, vol. 44, no. 63, 2018.

[54]P. Lotton, P. Blanc-benon, M. Bruneau, V. Gusev, S. Duffourd, M. Mirnov, G. Poignand, Transient temperature profile inside thermoacoustic refrigerators, Int. J. Heat Mass Transf., vol. 52, no. 21-22, pp. 4986-4996, 2009.

[55]A. Nathad, F. Ahmed, M. O. Khalid, R. Kumar, H. Hafeez, Experimental Analysis of an Economical Lab Demonstration Prototype of a Thermo Acoustic Refrigerator ( TAR ), Energy Procedia, vol. 157, pp. 343-354, 2019.

[56]B. R. Nayak, G. Pundarika and B. Arya, Influence of stack geometry on the performance of thermoacoustic refrigerator, Sadhana - Acad. Proc. Eng. Sci., vol. 42, no. 2, pp. 223-230, 2017.

[57]E. C. Nsofor and A. Ali, Experimental study on the performance of the thermoacoustic refrigerating system, Appl. Therm. Eng., vol. 29, no. 13, pp. 2672-2679, 2009.

[58]N. Putra and D. Agustina, Influence of stack plate thickness and voltage input on the performance of loudspeaker-driven thermoacoustic refrigerator, J. Phys. Conf. Ser., vol. 423, no. 1, 2013.

[59]Q. Tu and V. Gusev, Experimental and theoretical investigation on frequency characteristic of loudspeaker-driven thermoacoustic refrigerator, Cryogenics, vol. 45, pp. 739-746, 2006.

[60]D. A. Russell and P. Weibull, Tabletop thermoacoustic refrigerator for demonstrations, Am. J. Phys., vol. 70, no. 12, pp. 1231-1233, 2002.

[61]C. A. A. Atis, M. Sarker and M. Ehsan, Study of thermoacoustic phenomenon in a Rijke tube, Procedia Eng., vol. 90, pp. 569-574, 2014.

[62]I. Setiawan, A. B. Setio-utomo, M. Nohtomi and M. Katsuta, Experimental Study on Thermoacoustic Cooling System with Two Stacks in a Straight Resonator Tube, 10ème Congrès Français d'Acoustique Lyon, 2010.

[63]L. K. Tartibu, Maximum cooling and maximum efficiency of thermoacoustic refrigerators, Heat Mass Transf., vol. 52, no. 1, pp. 95-102, 2016.

[64]S. H. Tasnim, S. Mahmud and R. A. Fraser, Measurements of thermal field at stack extremities of a standing wave thermoacoustic heat pump, Front. Heat Mass Transf., vol. 2, no. 1, pp. 1-10, 2011.

[65]K. Amirin and M. Yulianto, Experimental study of thermoacoustic cooling with parallel-plate stack in different distances, IOP Conf. Series: Materials Science and Engineering, vol. 539, 2019.

[66]C. Wantha and K. Assawamartbunlue, The impact of the resonance tube on performance of a thermoacoustic stack, Front. Heat Mass Transf., vol. 2, no. 4, pp. 1-8, 2011.

[67]C. Wantha and K. Assawamartbunlue, Experimental investigation of the effects of driver housing and resonance tube on the temperature difference across a thermoacoustic stack, Heat Mass Transf. vol. 49, no. 6, pp. 887-896, 2013. 